\title{
Structure-Reactivity Relationships of L-Proline Derived Spirolactams and a-Methyl Prolinamide Organocatalysts in the Asymmetric Michael Addition Reaction of Aldehydes to Nitroolefins.
}

Fintan Kelleher

Technological University Dublin, fintan.kelleher@tudublin.ie

Sinead Kelly

Technological University Dublin

John Watts

Technological University Dublin

See next page for additional authors

Follow this and additional works at: https://arrow.tudublin.ie/ittsciart

Part of the Organic Chemistry Commons

\section{Recommended Citation}

Kelleher, F., Kelly, S., Watts, J. and McKee, V. Structure-reactivity relationships of L-proline derived spirolactams and a-methyl prolinamide organocatalysts in the asymmetric Michael addition reaction of aldehydes to nitroolefins. Tetrahedron Volume 66, Issue 19, 8 May 2010, Pages 3525-3536. DOI: 10.1016/j.tet.2010.03.002 ...

This Article is brought to you for free and open access by the School of Science and Computing at ARROW@TU Dublin. It has been accepted for inclusion in Articles by an authorized administrator of ARROW@TU Dublin. For more information, please contact arrow.admin@tudublin.ie, aisling.coyne@tudublin.ie, gerard.connolly@tudublin.ie. Funder: Irish Government 


\section{Authors}

Fintan Kelleher, Sinead Kelly, John Watts, and Vickie McKee

This article is available at ARROW@TU Dublin: https://arrow.tudublin.ie/ittsciart/6 
Structure-reactivity relationships of L-proline derived spirolactams and $\alpha$ methyl prolinamide organocatalysts in the asymmetric Michael addition reaction of aldehydes to nitroolefins.

Fintan Kelleher, ${ }^{\mathrm{a}}{ }^{\mathrm{a}}$ Sinead Kelly, ${ }^{\mathrm{a}}$ John Watts ${ }^{\mathrm{a}}$ and Vickie McKee ${ }^{\mathrm{b}}$

${ }^{\mathrm{a}}$ Molecular Design and Synthesis Group, Department of Science, Institute of Technology Tallaght, Dublin 24, Ireland.

${ }^{b}$ Chemistry Department, Loughborough University, Loughborough, Leics. LE11 3TU, $U K$.

Corresponding Author: Dr. Fintan Kelleher

Address: $\quad$ Department of Science,

Institute of Technology Tallaght,

Tallaght,

Dublin 24,

Ireland.

Phone Number: $\quad$ (+353 1) 4042869

Fax Number: $\quad$ (+353 1) 4042700

e-mail address: $\quad$ fintan.kelleher@ittdublin.ie

Graphical abstract :

Structure-reactivity relationships of L-proline derived spirolactams and $\alpha$-methyl prolinamide organocatalysts in the asymmetric Michael addition reaction of aldehydes to nitroolefins.

Fintan Kelleher,* Sinead Kelly, John Watts and Vickie McKee

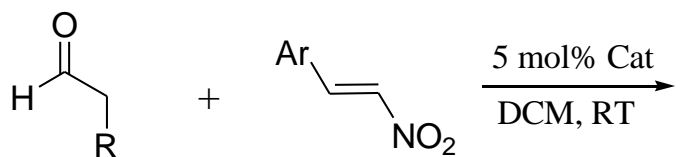

70-98\% yield up to 98:2 Syn/Anti, up to $82 \%$ e.e. (Syn)<smiles>[R]C(C=O)C(Br)C[N+](=O)[O-]</smiles>$$
\text { - }
$$

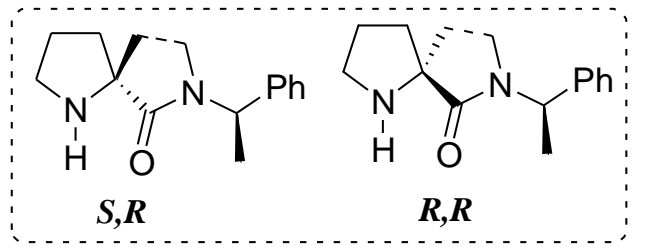


Structure-reactivity relationships of L-proline derived spirolactams and $\alpha$ methyl prolinamide organocatalysts in the asymmetric Michael addition reaction of aldehydes to nitroolefins.

Fintan Kelleher, ${ }^{* a}$ John Watts, ${ }^{a}$ Sinead Kelly ${ }^{a}$ and Vickie McKee ${ }^{b}$

${ }^{a}$ Molecular Design and Synthesis Group, Department of Science, Institute of Technology Tallaght, Dublin 24, Ireland.

${ }^{b}$ Chemistry Department, Loughborough University, Loughborough, Leics. LE11 3TU, $U K$.

\begin{abstract}
:
L-Proline derived spirolactams and $\alpha$-methyl prolinamides act as organocatalysts for the asymmetric conjugate addition of aldehydes to nitroolefins in excellent yields, with good diastereoselectivity and enantioselectivity. Furthermore, low catalyst loadings (5 mol\%) and a low aldehyde molar excess (1.5 molar equivalents) were achieved.
\end{abstract}

\title{
Keywords
}

Spirolactam; $\alpha$-methyl prolinamide; Asymmetric Organocatalysis; Michael addition reaction.

\section{Introduction}

The field of organocatalysis has seen an explosion of interest in the last decade. ${ }^{1}$ In particular, L-proline derived compounds have found use as organocatalysts in the asymmetric Michael addition reaction of aldehydes and ketones to nitroolefins, with the products being produced in high yields, with excellent diastereo- and enantioselectivities (Figure 1). ${ }^{1-6}$ However, in many earlier cases either a large excess of the aldehyde or ketone is required (10-20 molar equivalents) or high levels of catalysts (10-25 mol\%). More recently highly efficient catalyst systems for this transformation have been developed and are the benchmark for all new catalysts. Ma 
was able to achieve high yields and selectivities using only $0.5 \mathrm{~mol} \%$ of 4 and 1.5 equivalents of aldehyde in the presence of benzoic acid as an additive. ${ }^{3}$ However, Lombardo recently reported the use of the ion-tagged diphenylprolinol silyl ether 7 which achieves enantiomeric excesses of $>99.5 \%$ at low catalyst loadings (0.25-5 mol\%), and uses only a slight excess of aldehydes (1.2-2 molar equivalents). ${ }^{4}$ The most efficient catalyst reported to-date is the tripeptide $\mathbf{8}$ described by Wennemers. ${ }^{5}$ This catalyst is highly efficient at levels of only 0.1-0.2 mol\%, even with the nitroalkene in excess, giving high yields and selectivities for a range of aldehydes and nitroalkenes. The usefulness of the products from these reactions resides in the potential for further transformation of both the nitro and carbonyl functionalities.<smiles>C1CNC(c2nnn[nH]2)C1</smiles>

1<smiles>C1CNC(CN2CCCC2)C1</smiles>

2<smiles>CC(C)N1CCC[C@H]1[C@H]1CCCN1</smiles>

3

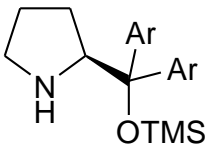

4<smiles>O=C(C1CC(O)CN1)N1CCC[C@H]1C(c1ccccc1)c1ccccc1</smiles><smiles>O=C(N[C@H](Cc1ccccc1)C(O)(c1ccccc1)c1ccccc1)[C@@H]1C[C@@H](O)CN1</smiles>

6<smiles></smiles><smiles>NC(=O)[C@H](CCC(=O)O)NC(=O)[C@@H]1CCCN1C(=O)[C@@H]1CCCN1</smiles><smiles>C1CCN([C@@H]2CCC[C@]23CCCN3)C1</smiles>

Figure 1. Proline and 4-hydroxyproline derived organocatalysts. ${ }^{1-6}$

There is an ongoing requirement for the development of new organocatalysts for this and other important chemical transformations, in order to fully understand the structure-reactivity relationships of these catalysts. Many of the reported prolinederived catalysts are conformationally flexible in nature and it was thought that the introduction of conformational constraints into the structure could lead to more specific catalysts, which might allow the use of lower amounts of aldehyde or ketone, along with the requirement for low levels of the organocatalyst (e.g. 5\% or less). One way to introduce such conformational constraint would be to have, for example, the L- 
proline as part of a rigid spiro fused ring system. Royer recently prepared such a rigid pyrrolidino spiro diamine (9, Figure 1) and it exhibited limited success in its ability to act as an asymmetric organocatalyst in the Michael addition reaction of aldehydes to nitroolefins, although only one set of reaction conditions was reported. ${ }^{6}$ Rather than having the second amino group as an exocyclic substituent, incorporation of the second nitrogen atom as part of the ring would give spirolactam and spirodiamine structures.

\section{Results and Discussion}

As part of a program to synthesise both enantiomerically pure and racemic prolinederived [4.4]-spirolactams, we recently reported our studies on their preparation by thermal intramolecular ester aminolysis methods. ${ }^{7}$ Diastereoisomeric spirolactams (11a and 11b) were prepared and separated chromatographically (Figure 2).<smiles>[2H]N1CCC[C@]12CCN([C@H](C)c1ccccc1)C2=O</smiles><smiles>[R]N1CCC[C@]12CCN([C@H](C)c1ccccc1)C2=O</smiles>

$\mathrm{R}=\mathrm{Boc} 11 \mathrm{a}$ $=\mathrm{H} \quad$ 12a $\mathrm{R}=\mathrm{Boc} 11 \mathrm{~b}$ $=\mathrm{H} \quad \mathbf{1 2 b}$<smiles>CC(c1ccccc1)N1CCC2(CCCN2)C1</smiles>

13a<smiles>[2H]N1CCC[C@]12CCN(C(C)c1cccc3ccccc13)C2=O</smiles>

$\mathrm{R}=$ Boc 14a<smiles>CC(c1ccccc1)N1CC[C@]2(CCCN2)C1</smiles>

13b<smiles>[R]N1CCC[C@]12CCN(C(C)c1cccc3ccccc13)C2=O</smiles>

$\mathrm{R}=$ Boc 14b $=\mathrm{H} \quad 15 b$

Figure 2. Synthesised spirolactam and spirodiamine organocatalysts

It was also found that the spiro diamine derivatives $13 \mathrm{a}$ and $\mathbf{1 3 b}$ complexed a zinc ion. ${ }^{7 \mathrm{c}}$ Although the stereochemistry of the $\alpha$-methyl benzyl substituent was known, from the choice of the starting amine, the absolute stereochemistry of the spiro centre in each of the diastereoisomers was not known. Previously, we were unable to grow crystals of sufficient quality for X-ray analysis to be obtained, so NMR spectroscopy 
along with molecular modelling ${ }^{7 \mathrm{c}}$ was used to tentatively assign the stereochemistry of the $S R$ and $R R$ diastereoisomeric pair, 11a and 11b. Eventually crystals of sufficient quality were obtained of $\mathbf{1 1 b}$, by crystallisation from hexane, and an X-ray crystal structure was obtained (Figure 3), which confirmed the previous NMR spectroscopic and modelling assignments. ${ }^{7 b, c}$

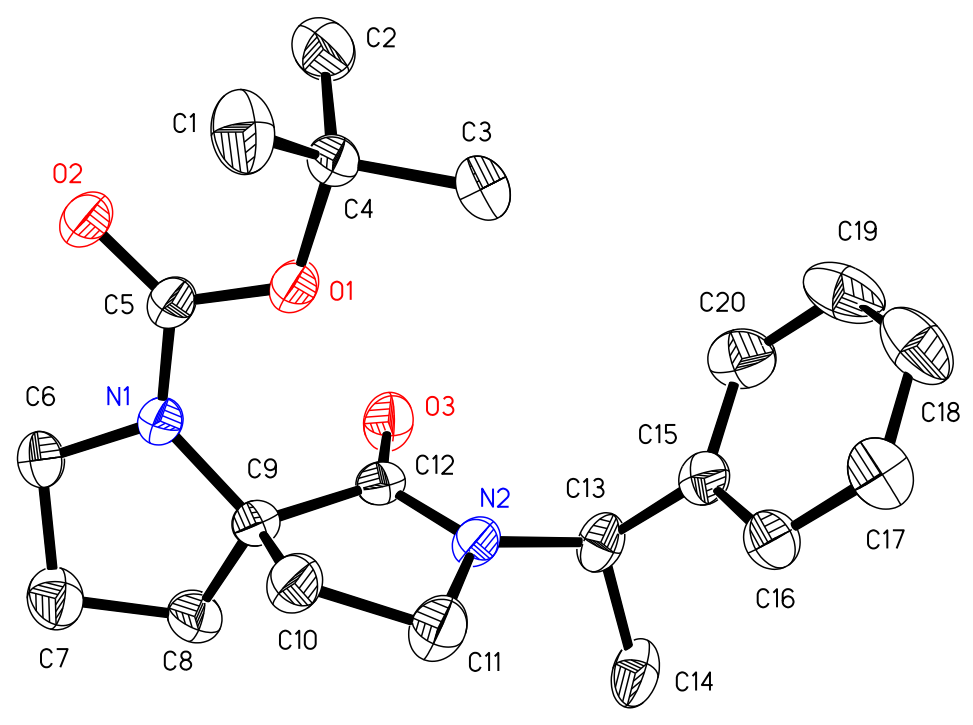

Figure 3. Perspective view of $\mathbf{1 1 b}$ showing $50 \%$ probability ellipsoids. Hydrogen atoms omitted for clarity.

The X-ray crystal structure clearly shows the $R$ absolute stereochemistry at the spiro centre. As a result of this structure, the absolute stereochemistry of both diastereoisomers was now known. Treatment of 11a and 11b with trifluoroacetic acid gave the desired deprotected compounds 12a and 12b. An examination of the structures of these compounds shows that they can be considered as conformationally constrained analogues of prolinamides, an important class of organocatalysts. Therefore the investigation of the use of spirolactams 12a and 12b as organocatalysts in the model reaction of valeraldehyde with trans- $\beta$-nitrostyrene was undertaken (Table 1).

Table 1. Michael addition reaction of valeraldehyde to $\beta$-nitrostyrene. 


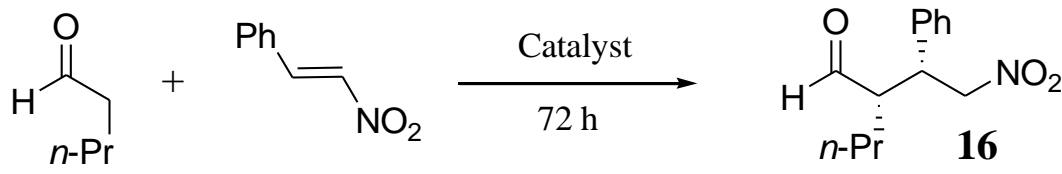

\begin{tabular}{|c|c|c|c|c|c|c|c|c|c|}
\hline Entry & Solvent & Cat & Add & $\begin{array}{c}\text { Loading } \\
\text { (mol\%) }\end{array}$ & $\begin{array}{l}\text { Aldehyde } \\
\text { (mol eq.) }\end{array}$ & Temp. & Yield $^{\mathrm{a}}$ & $d r^{b}$ & $e^{c} e^{c}$ \\
\hline 1 & DCM & $12 \mathrm{a}$ & - & 5 & 1.5 & RT & 98 & $62: 38$ & 66 \\
\hline 2 & $\mathrm{CHCl}_{3}$ & $12 \mathrm{a}$ & - & 5 & 1.5 & RT & 98 & $65: 35$ & 65 \\
\hline 3 & $i$-PrOH & $12 a$ & - & 5 & 1.5 & RT & 98 & $67: 33$ & 45 \\
\hline 4 & THF & $12 a$ & - & 5 & 1.5 & RT & 43 & $74: 26$ & 80 \\
\hline 5 & DMSO & $12 \mathrm{a}$ & - & 5 & 1.5 & RT & 80 & $74: 26$ & 25 \\
\hline 6 & DCM & $12 \mathrm{a}$ & - & 5 & 1.5 & 4 & 77 & $70: 30$ & 76 \\
\hline 7 & DCM & $12 a$ & - & 5 & 10 & RT & 90 & $73: 27$ & 80 \\
\hline 8 & DCM & $12 a$ & - & 20 & 10 & RT & 98 & 64:36 & 72 \\
\hline 9 & DCM & $12 \mathrm{~b}$ & - & 5 & 1.5 & RT & 98 & $67: 33$ & $63^{d}$ \\
\hline 10 & $\mathrm{CHCl}_{3}$ & $12 \mathrm{~b}$ & - & 5 & 1.5 & RT & 96 & $65: 35$ & $68^{d}$ \\
\hline 11 & $i$-PrOH & $12 \mathrm{~b}$ & - & 5 & 1.5 & RT & 72 & $68: 32$ & $63^{d}$ \\
\hline 12 & $\mathrm{DCM}$ & $12 \mathrm{~b}$ & TFA & 5 & 1.5 & RT & 71 & $60: 40$ & $53^{d}$ \\
\hline 13 & DCM & $15 a$ & - & 5 & 1.5 & RT & 98 & $62: 38$ & 32 \\
\hline 14 & DCM & $15 \mathrm{~b}$ & - & 5 & 1.5 & RT & 98 & $71: 29$ & $56^{\mathrm{d}}$ \\
\hline
\end{tabular}

${ }^{\text {a }}$ Isolated yield after chromatography

${ }^{\mathrm{b}}$ Syn:anti ratio determined by ${ }^{1} \mathrm{H}$ NMR spectroscopy

c e.e. of syn isomer determined by chiral HPLC

${ }^{\mathrm{d}}$ Opposite enantiomer of the syn product

The first reaction was conducted using a low molar excess of valeraldehyde (1.5 equivalents) in dichloromethane at room temperature for $72 \mathrm{~h}$ in the presence of 5 mol\% of $(S, R)$-spirolactam 12a (entry 1). Product 16 was isolated in $98 \%$ yield, with a syn:anti ratio of 62:38, and the enantiomeric excess (e.e.) of the syn isomer was $66 \%$. Changing the solvent to chloroform or 2-propanol gave similar results, while the use of THF as solvent gave a better syn:anti ratio of 74:26 and an e.e. of $80 \%$ for the syn isomer, although the isolated yield was much reduced at 43\% (entries 2, 3 and 4). DMSO gave an $80 \%$ yield, with a syn:anti ratio of $74: 26$, but a poor e.e. of only $25 \%$ (entry 5). For further studies, DCM was used as solvent. The effect of temperature on the outcome of the reaction was examined by running the reaction at $4{ }^{\circ} \mathrm{C}$ (entry 6 ). In this case, the isolated yield was reduced to $77 \%$, while the syn:anti ratio improved to $70: 30$, with the syn isomer having an improved e.e. of $76 \%$, when compared to the reaction at room temperature. Increasing the amount of valeraldehyde to 10 molar equivalents surprisingly gave a slight reduction in isolated yield to $90 \%$, when compared to the use of 1.5 molar equivalents (98\%, entry 1), but with an improved syn:anti ratio of $73: 27$, and an e.e. of $80 \%$ for the syn isomer (entry 7 ). Repeating this 
reaction with $20 \mathrm{~mol} \%$ of the catalyst, brought the isolated yield back to $98 \%$, but unfortunately, the syn:anti ratio reduced to $64: 36$, with a concomitant reduction in the e.e. of the syn isomer to $72 \%$ (entry 8 ).

Use of the diastereoisomeric $(R, R)$-spirolactam $\mathbf{1 2 b}$ as catalyst, under the standard conditions, gave similar isolated yields to those obtained with 12a, with similar syn:anti ratios (Entries 9, 10 and 11). The enantiomeric excesses were also similar but, most importantly, in these cases the opposite enantiomer of the syn diastereoisomer now predominated, as shown by chiral HPLC analysis. Other groups have observed an improvement in both the diastereoisomeric ratio and the e.e. of the syn isomer on the addition of acidic additives, such as trifluoroacetic acid (TFA). Addition of 1 molar equivalent of TFA, using spirolactam 12b as catalyst, gave a reduced isolated yield, with poorer diastereocontrol (Entry 12). All of these results show that it is the absolute stereochemistry of the spiro centre which is controlling the observed enantioselectivity, with the stereochemistry of the side-chain substituent having little effect. This is not surprising if the proposed transition state models of the reactions are considered (Figure 4). 


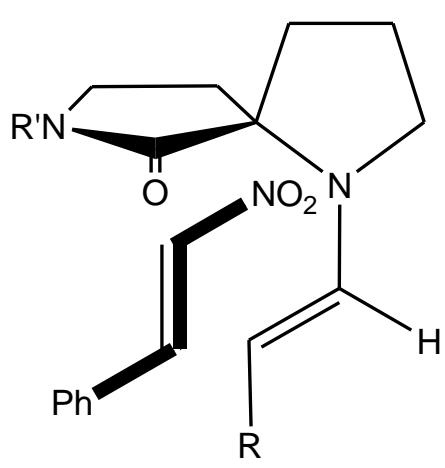

$\operatorname{Re}, \operatorname{Re}-1$

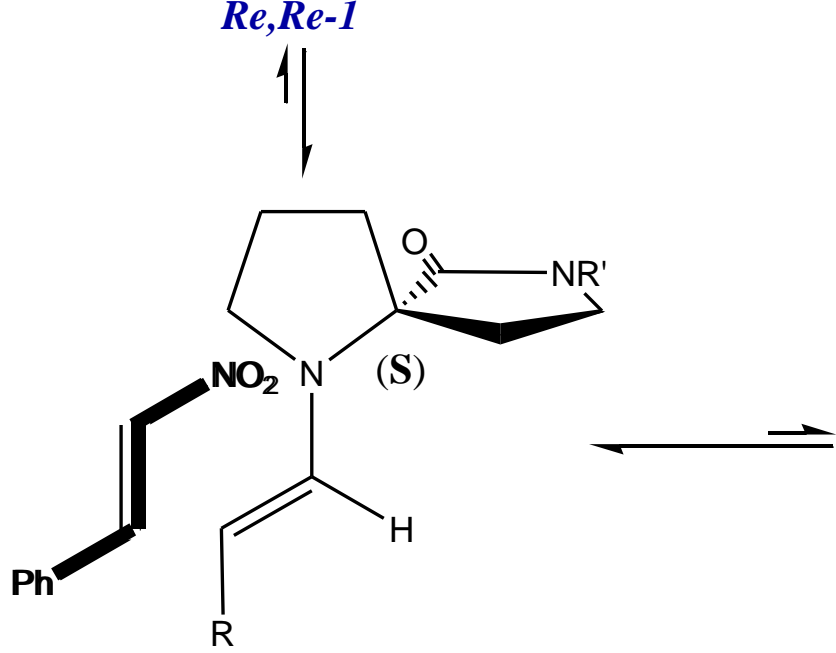

Re, Re-2

$$
\downarrow
$$<smiles>O=C[C@H](P)[C@@H](C[N+](=O)[O-])c1ccccc1</smiles>

$16(S, R)$

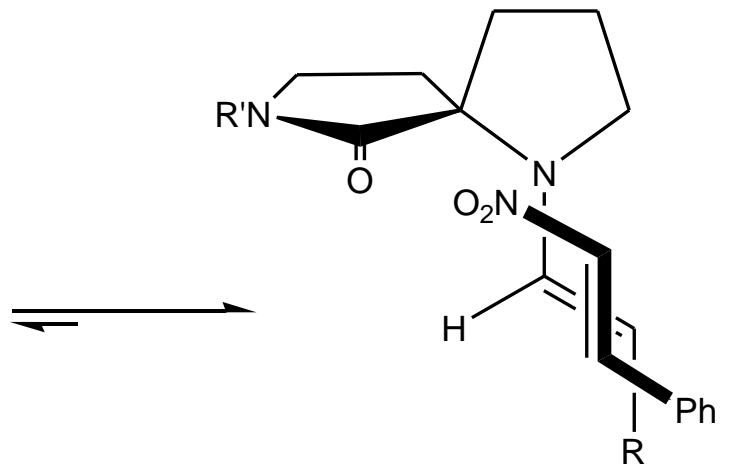

Si,Si-1

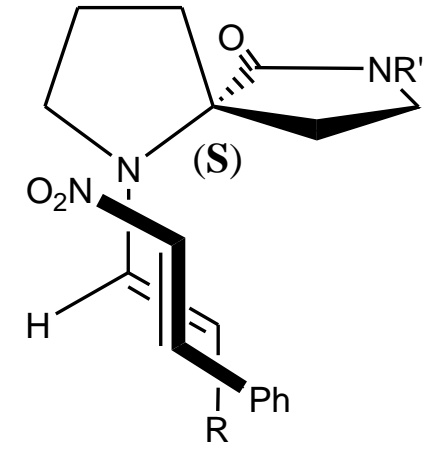

Si,Si-2

MAJOR<smiles>O=C[C@H](P)[C@H](C[N+](=O)[O-])c1ccccc1</smiles>

$16(R, S)$

\section{MINOR}

Figure 4. Proposed transition state model for Michael addition reaction of valeraldehyde with $\beta$-nitrostyrene using spirolactam catalysts.

The syn diastereoselectivity observed is due to the "Seebach acyclic synclinal model", ${ }^{8}$ in which there are favourable electrostatic interactions in the transition state between the enamine nitrogen and the nitro group. For the syn diastereoisomeric pair the $R e$ face of the nitrostyrene can approach the enamine $R e$ face in two different 
ways ( $\boldsymbol{R e}, \boldsymbol{R e}-\mathbf{1}$ and $\boldsymbol{R e}, \boldsymbol{R e}-\mathbf{2}$, Figure 4), depending on whether it approaches from the same, or opposite, side as the lactam carbonyl group. Similarly the Si face of the nitro styrene can approach enamine $\mathrm{Si}$ face in two ways (Si,Si-1 and $\mathbf{S i}, \mathbf{S i}-2)$. Of the two possible $R \boldsymbol{e}, \operatorname{Re}$ trajectories $\boldsymbol{R e}, \boldsymbol{R e}-\mathbf{2}$ is the much more likely because there are two destabilising steric interactions present in the $\boldsymbol{R e}, \boldsymbol{R} \boldsymbol{e}-\boldsymbol{1}$ trajectory, namely the less favourable enamine rotamer as well as the interaction of the nitrostyrene with the lactam carbonyl group. Neither of these interactions are present in the $\boldsymbol{R e}, \boldsymbol{R e}-\boldsymbol{I}$ trajectory. Of the two possible $\mathrm{Si}, \mathrm{Si}$ trajectories $\mathbf{S i , S i - 1}$ has the favourable enamine rotamer but a steric interaction with the lactam carbonyl, while $\mathbf{S i , S i - 2}$ has a steric interaction with the methylene of the lactam ring, as well as being the less favoured enamine rotamer. It is therefore not apparent which of these trajectories is more favoured. Overall, it is thus the contribution of favourable electrostatic interactions as well as the unfavourable steric interactions which controls the observed diastereoselecetivity and enantioselectivity. In the case of the use of the spirolactam 12b as catalyst, with the opposite stereochemistry at the spirocentre, the transition state with the Si,Si approach of the faces of the $\beta$-nitrostyrene and the enamine would be the predominant pathway, thus giving the observed $(R, S)$ enantiomer as the major product.

Increasing the steric bulk of the spirolactam side-chain was achieved by replacing the phenyl group with the 1-naphthyl group. The spirolactams were synthesised in an analogous manner to the phenyl substituted compounds, ${ }^{7 \mathrm{c}}$ but $(R)-(1)-(1-$ naphthyl)ethylamine was used in place of $(R)$-(1)-phenylethylamine. As before the two diastereoisomeric spirolactams, $\mathbf{1 4 a}$ and $\mathbf{1 4 b}$, were separable. Their stereochemistries were tentatively assigned by comparison of their NMR spectral data (chemical shifts and coupling constants) with the phenyl-derived compounds, as well as their relative polarities as measured by TLC analysis. Use of the Boc deprotected compounds $15 \mathrm{a}$ or $\mathbf{1 5} \mathrm{b}$ in the Michael addition reaction gave similar yields and diastereoselectivities to those of the corresponding phenyl derivatives $12 \mathbf{a}$ and $\mathbf{1 2} \mathbf{b}$, but with slightly lower enantioselectivities (Table 1, entries 13 and 14). This confirms that the lactam side-chain is having little effect on the stereochemical outcome of the reaction. 
The scope of the catalysts (12a and $12 \mathbf{b}$ ) was examined by reacting different aldehydes and $\beta$-nitrostyrenes under the optimised conditions (Table 2). Propionaldehyde showed poor diastereo- and enantioselectivity (d.r. 62:38, e.e. 34\%) and a reduced isolated yield of $77 \%$ (entry 1), while the more hindered isovaleraldehyde showed excellent diastereocontrol (d.r. 89:11) and a hugely improved e.e. of $82 \%$ (entry 2). Unfortunately, the isolated yield was poor (22\%) due to the increased steric effect of the branched aldehyde. Reaction of valeraldehyde with substituted $\beta$-nitrostyrenes show similar diastereo- and enatioselectivity to the parent $\beta$-nitrostyrene (entries 3-8). The reason for the very poor enantioselectivity of catalyst 12b (4\% e.e.) with the para-methoxy substituted $\beta$-nitrostyrene (entry 6) is not known.

Table 2. Michael addition reaction of aldehydes to $\beta$-nitrostyrenes<smiles>[R]CC(=O)CC(=O)CC(Br)C[N+](=O)[O-]</smiles>

\begin{tabular}{|c|c|c|c|c|c|c|}
\hline Entry & Cat & $\mathbf{R}^{\mathbf{1}}$ & $\mathbf{A r}$ & Yield $^{\mathbf{a}}$ & $\mathbf{d r}^{\mathbf{b}}$ & $\mathbf{e e}^{\mathbf{c}}$ \\
\hline 1 & 12b & $\mathrm{Me}$ & $\mathrm{Ph}$ & 77 & $62: 38$ & 34 \\
\hline 2 & 12b & $i-\mathrm{Pr}$ & $\mathrm{Ph}$ & 22 & $89: 11$ & 82 \\
\hline 3 & 12a & $n-\mathrm{Pr}$ & $p$-tolyl & 94 & $60: 40$ & 54 \\
\hline 4 & 12b & $n-\mathrm{Pr}$ & $p$-tolyl & 90 & $63: 37$ & $62^{\mathrm{d}}$ \\
\hline 5 & 12a & $n-\mathrm{Pr}$ & $p-\mathrm{MeOC} \mathrm{H}_{4}$ & 86 & $56: 44$ & 78 \\
\hline 6 & 12b & $n-\operatorname{Pr}$ & $p-\mathrm{MeOC}_{6} \mathrm{H}_{4}$ & 82 & $57: 43$ & $4^{\mathrm{d}}$ \\
\hline 7 & 12a & $n-\mathrm{Pr}$ & $p-\mathrm{ClC}_{6} \mathrm{H}_{4}$ & 90 & $55: 45$ & 51 \\
\hline 8 & 12b & $n-\mathrm{Pr}$ & $p-\mathrm{ClC}_{6} \mathrm{H}_{4}$ & 92 & $62: 38$ & $73^{\mathrm{d}}$ \\
\hline
\end{tabular}

Reactions carried out with 1.5 molar equivalents of aldehyde.

${ }^{\text {a }}$ Isolated yield after chromatography

${ }^{\mathrm{b}}$ Syn:anti ratio determined by ${ }^{1} \mathrm{H}$ NMR spectroscopy

${ }^{c}$ e.e. of syn isomer determined by chiral HPLC

${ }^{\mathrm{d}}$ Opposite enantiomer of the syn product

Many of the reported catalysts used to catalyse the Michael addition reaction of aldehydes and ketones to nitroolefins have been diamines derived from L-proline (Figure 1). ${ }^{1,2,6}$ For comparison, spirodiamines 13a and 13b were prepared, from spirolactams 12a and $\mathbf{1 2} \mathrm{b}$, by removing the Boc group and reducing the lactam ring to the cyclic amine with lithium aluminium hydride. ${ }^{7 \mathrm{c}}$ When $13 \mathrm{a}$ was used as a catalyst 
in the Michael addition reaction similar syn:anti ratios were obtained, to those when the corresponding spirolactams were used, though the isolated yield was only $85 \%$ (Table 3, entry 1).

Table 3. Michael addition reaction of valeraldehyde to $\beta$-nitrostyrene catalysed by diamines 13a and 13b.

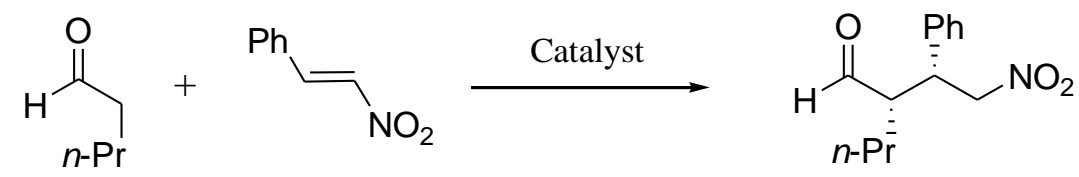

\begin{tabular}{|c|c|c|c|c|c|c|c|}
\hline Entry & Cat & Additive & $\begin{array}{c}\text { Loading } \\
(\mathbf{m o l} \%)\end{array}$ & $\begin{array}{c}\text { Aldehyde } \\
\text { (mol eq.) }\end{array}$ & Yield $^{\mathbf{a}}$ & $\mathbf{d r}^{\mathbf{b}}$ & $\mathbf{e e}^{\mathbf{c}}$ \\
\hline 1 & 13a & - & 5 & 1.5 & 85 & $65: 35$ & 2 \\
\hline 2 & 13b & - & 5 & 1.5 & 85 & $68: 32$ & $14^{\mathrm{d}}$ \\
\hline 3 & 13a & - & 20 & 10 & 98 & $67: 33$ & 2 \\
\hline 4 & 13a & TFA & 5 & 1.5 & 99 & $61: 39$ & 3 \\
\hline 5 & 13a & HCl & 5 & 1.5 & 99 & $62: 38$ & 0 \\
\hline 6 & 13b & TFA & 5 & 1.5 & 98 & $65: 35$ & $3^{\mathrm{d}}$ \\
\hline
\end{tabular}

Reactions carried out in DCM at ambient temperature, for 72 hours.

${ }^{a}$ Isolated yield after chromatography

${ }^{\mathrm{b}}$ Syn:anti ratio determined by ${ }^{1} \mathrm{H}$ NMR spectroscopy

${ }^{c}$ e.e. of syn isomer determined by chiral HPLC

${ }^{\mathrm{d}}$ Opposite enantiomer of the syn product

In these cases, however, the enantioselectivity was severely reduced, with the syn isomer now being obtained in close to racemic form. Increasing the amount of catalyst to $20 \mathrm{~mol} \%$ only increased the isolated yield back to $98 \%$, with no effect on the stereoselectivity of the reaction (entry 3). The addition of TFA or $\mathrm{HCl}$ as an additive, or using the epimeric spiro diamine 13b, had no effect on this outcome (entries 2, 4, 5 and 6). The selectivity of substituted pyrrolidine-based organocatalysts in the Michael addition reaction is mostly determined by the nature of the substitutent in the 2position (trans-4-hydroxy substitutents also exert control). ${ }^{1 \mathrm{j}}$ For substituents with a hydrogen bond donor present (e.g. $\mathrm{COOH}$ in L-proline or the N-H in prolinamides and sulfonamides), it is the attractive interaction with the nitro group of the styrene and the hydrogen bond donor which controls the facial selectivity. ${ }^{1 \mathrm{a}, 1 \mathrm{j}}$ In the absence of such hydrogen bond donors the facial selectivity is controlled by the steric effect of 
the pyrrolidine side-chain. In this study, there is no hydrogen bond donor present in the spirolactams and thus the facial selectivity is as described previously. The results with the diamines 13a and 13b can be explained by examining the transition state model of the reaction (Figure 4). In the absence of the lactam carbonyl group the $\boldsymbol{R e}, \boldsymbol{R e}-\mathbf{2}$ and $\mathbf{S i}, \mathrm{Si}-\mathbf{1}$ trajectories are equally likely, since there is now a methylene attached to both sides of the quaternary spiro carbon. This leads to equal steric preference for the $\boldsymbol{R e}, \boldsymbol{R e}-\mathbf{2}$ and $\mathbf{S i}, \mathrm{Si}-\mathbf{1}$ trajectories and thus racemic products are obtained. In this case although the spiro diamine is more conformationally flexible, the bulky nitrogen side-chain is too remote from the spiro centre to have any impact on the stereocontrol.

It would be envisaged that either breaking the lactam ring to give more conformational flexibility (17) or removal of the spiro fusion completely, to give simple prolinamides $\mathbf{1 8}$, might lead to improvements in the observed stereocontrol (Figure 5).

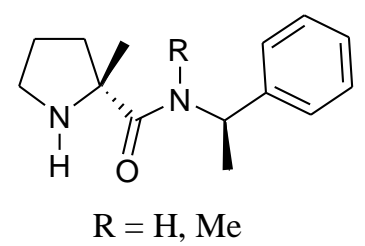

17<smiles>[R]N(C(=O)[C@@H]1CCCN1)C(C)c1ccccc1</smiles>

$\mathrm{R}=\mathrm{H}, \mathrm{Me}$

18

Figure 5. Conformationally flexible spirolactam analogues.

For direct comparison with the spirolactam studies it was decided to keep the $\alpha$ methyl benzylamine sidechains. The synthesis of the two sets of four stereoisomers of 17 ( $\mathrm{R}=\mathrm{Me}$ or $\mathrm{H})$ started from $N$-Boc-L-proline methyl ester 19 (Scheme 1). 

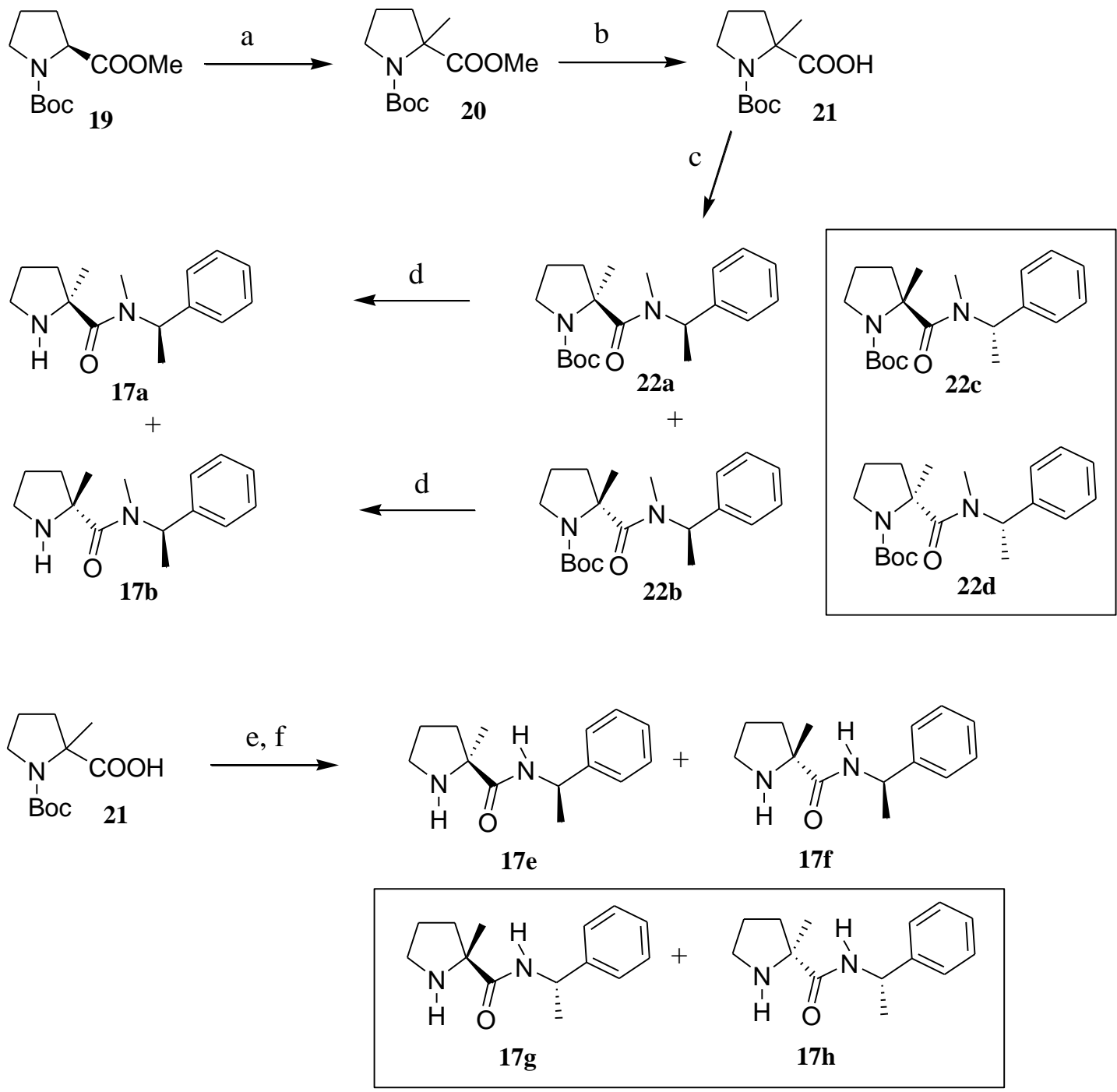

Scheme 1: Reagents and conditions; (a) i) LiHMDS, THF, $-78{ }^{\circ} \mathrm{C}$, ii) methyl iodide, rt, $72 \%$;

(b) i) $\mathrm{NaOH}, \mathrm{MeOH} / \mathrm{H}_{2} \mathrm{O}$, reflux, ii) $1 \mathrm{M} \mathrm{HCl}, 93 \%$; (c) $(R)-N$, $\alpha$-dimethylbenzyl amine, DIPEA, HATU, DMF, rt, 49\%; (d) 50\% TFA in DCM, rt, 88-92\%; (e) ( $R$ )- $\alpha$-methylbenzyl amine, DIPEA, HATU, DMF, rt, 94\%; (f) $50 \%$ TFA in DCM, rt, $93-96 \%$.

$\alpha$-Methylation of 19 with methyl iodide gave the racemic $\alpha$-methyl ester 20 in $72 \%$ yield, which was hydrolysed to the $\alpha$-methyl carboxylic acid 21 , in $93 \%$ yield. The racemic acid was then coupled, separately with $R$ - or $S$ - $N, \alpha$-dimethylbenzylamine, using HATU as the coupling agent, to give the four N-methylated diastereoisomeric $\alpha$-methyl prolinamides (22a-d). 21 was also coupled, separately, with $R$ - or $S$ - $\alpha$ methylbenzylamine, under similar conditions, to give the four $\mathrm{N}-\mathrm{H}$ stereoisomeric $\alpha$ methyl prolinamides $(22 \mathrm{e}-\mathbf{h})$. Removal of the Boc group in each of the eight compounds gave the free amines 17a-h. The relative stereochemistry of each compound was obtained from X-ray crystal structure data. Only one compound from each set gave crystals suitable for X-ray analysis (Figure 6). 


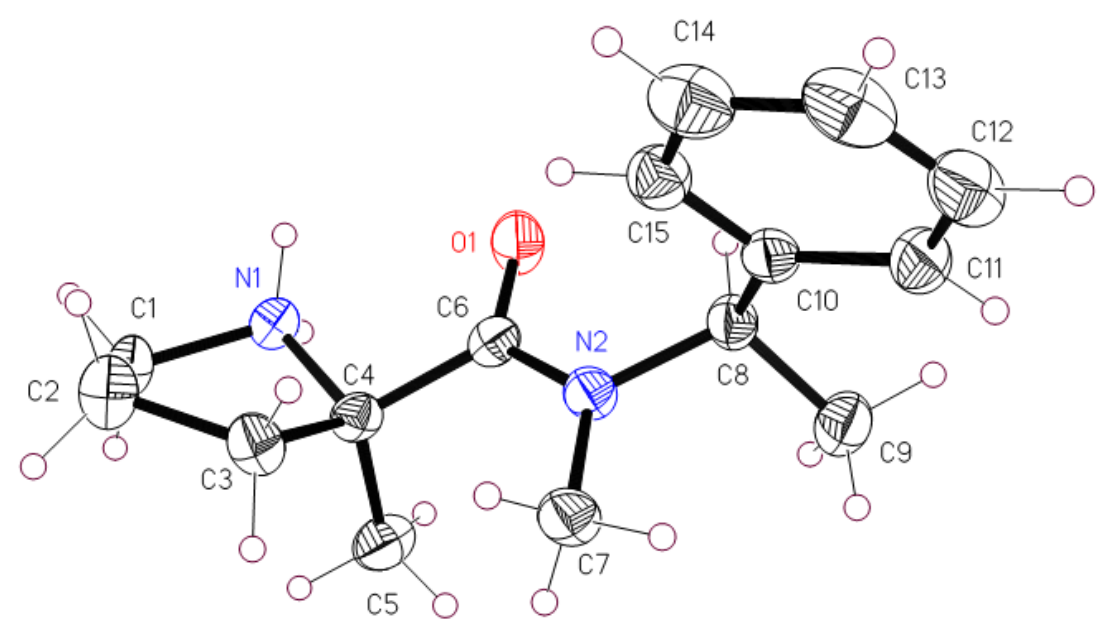

$17 \mathrm{~b}(R, R)$

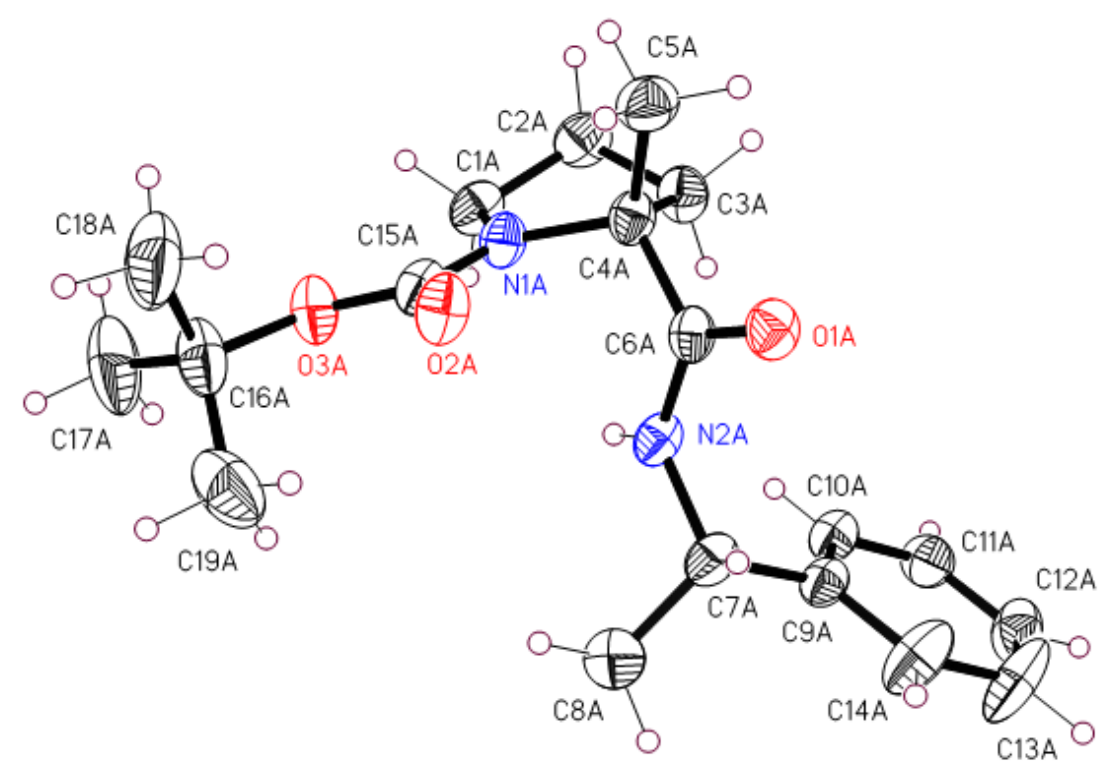

$22 \mathrm{~g}(R, S)$

Figure 6. X-ray structures of the cation of $17 \mathrm{~b}$ and one of the two independent conformations of $22 \mathrm{~g}$. Both structures are drawn with $50 \%$ probability ellipsoids. Tosyl anion in $\mathbf{1 7 b}$ has been omitted for clarity.

Since the stereochemistry of the amine side-chain was known, from the choice of amine starting material, the absolute stereochemistry of the quaternary centre was easily obtained. The crystalline side-chain $\mathrm{N}-\mathrm{H}$ compound was obtained as its Boc derivative $22 \mathrm{~g}$ ( $R, S$ stereochemistry) while the side-chain $N$-Me compound was obtained as its ammonium tosylate salt (17b.TsOH, $R, R$ stereochemistry). 
The simple L-prolinamides 18 were prepared from L-proline by Boc protection of the proline nitrogen, to give $N$-Boc-L-proline 23, in almost quantitative yield, followed by separately coupling to $R$ - or $S$ - $\alpha$-methylbenzylamine, to give the two diastereoisomeric prolinamides 24a and 24b (Scheme 2, only reaction with $(R)-\alpha$ methylbenzylamine to give $\mathbf{2 4 a}$ is shown).<smiles>COC(=O)C1CCCN1C(=O)c1ccccc1</smiles>

19<smiles>[13CH][TeH]</smiles><smiles>O=C(O)C1CCCN1C(=O)O</smiles><smiles>C/C=C(/C(=O)N(C)[C@H]1CCCN1C(=O)OCc1ccccc1)C(C)c1ccccc1</smiles>

$25 \mathrm{a}$

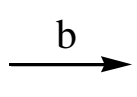

23

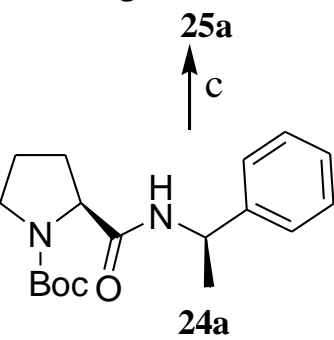<smiles>CC(C)(C)CNC(=O)[C@@H]1CCCN1</smiles>

Scheme 2: Reagents and conditions; (a) i) $\mathrm{NaOH}, \mathrm{MeOH} / \mathrm{H}_{2} \mathrm{O}$, reflux, ii) $1 \mathrm{M} \mathrm{HCl}, 98 \%$;

(b) $(R)$ - $\alpha$-methylbenzyl amine, DMAP, EDC, DCM, rt, $90 \%$; (c) i) LiHMDS, THF, $-78{ }^{\circ} \mathrm{C}$,

ii) methyl iodide, rt, $92 \%$; (d) 50\% TFA in DCM, rt, 86-91\%.

In these cases, efficient coupling was achieved using EDC, whereas HATU was necessary in the more sterically hindered coupling reactions above. $N$-methylation of 24a (or 24b), with methyl iodide, gave the $N$-methyl prolinamide 25a (or 25b). Deprotection of $24 \mathbf{a}$ and $24 \mathbf{b}$ gave the $N-\mathrm{H}$ L-prolinamides $18 \mathrm{a}$ and $18 \mathrm{~b}(\mathrm{R}=\mathrm{H})$, while deprotection of $25 \mathrm{a}$ and $25 \mathrm{~b}$ gave the $N$-Me L-prolinamides $18 \mathrm{c}$ and $18 \mathrm{~d}(\mathrm{R}=$ Me). Prolinamides $\mathbf{1 8} \mathbf{a}$ and $\mathbf{1 8 b}$ are known and have previously been described by Chimni as efficient organocatalysts, as their $\mathrm{HBr}$ salts, for the direct aldol reaction in water. ${ }^{9}$ Earlier $\mathrm{Wu}$ and Gong also described their use as enantioselective catalysts for direct aldol reactions. ${ }^{10}$

The $\alpha$-methyl prolinamides $17 \mathbf{a}, \mathbf{1 7 b}, \mathbf{1 7 e}$ and $17 \mathbf{f}$ and simple prolinamides $18 \mathrm{a}-\mathbf{d}$ were then examined as organocatalysts in the standard reaction (Table 4).

Table 4. Michael addition reaction of valeraldehyde to $\beta$-nitrostyrene catalysed by $17 \mathrm{a}, 17 \mathrm{~b}, 17 \mathrm{e}, 17 \mathrm{f}$ and $18 \mathrm{a}-\mathrm{d}$. 


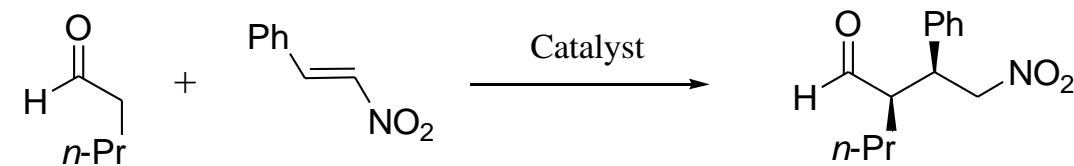

\begin{tabular}{|c|l|c|c|c|}
\hline Entry & Catalyst & Yield $^{\mathbf{a}}$ & $\mathbf{d r}^{\mathbf{b}}$ & $\mathbf{e e}^{\mathbf{c}}$ \\
\hline 1 & $\mathbf{1 7 a}(\boldsymbol{S}, \boldsymbol{R})$ & 98 & $61: 39$ & 40 \\
\hline 2 & $\mathbf{1 7 b}(\boldsymbol{R}, \boldsymbol{R})$ & 98 & $62: 38$ & $59^{\mathrm{d}}$ \\
\hline 3 & $\mathbf{1 7 e}(\boldsymbol{S}, \boldsymbol{R})$ & 55 & $56: 44$ & 63 \\
\hline 4 & $\mathbf{1 7 f}(\boldsymbol{R}, \boldsymbol{R})$ & 60 & $56: 44$ & $59^{\mathrm{d}}$ \\
\hline 5 & $\mathbf{1 8 a}(\boldsymbol{S}, \boldsymbol{R})$ & 98 & $77: 23$ & 71 \\
\hline 6 & $\mathbf{1 8 b}(\boldsymbol{S}, \boldsymbol{S})$ & 98 & $98: 2$ & 81 \\
\hline 7 & $\mathbf{1 8 c}(\boldsymbol{S}, \boldsymbol{R})$ & 98 & $93: 7$ & 49 \\
\hline 8 & $\mathbf{1 8 d}(\boldsymbol{S}, \boldsymbol{S})$ & 94 & $94: 6$ & 65 \\
\hline
\end{tabular}

Reactions carried out in DCM with 1.5 molar equivalents of aldehyde, at ambient temperature, for 48 hours.

${ }^{\text {a }}$ Isolated yield after chromatography

${ }^{\mathrm{b}}$ Syn:anti ratio determined by ${ }^{1} \mathrm{H}$ NMR spectroscopy

${ }^{c}$ e.e. of syn isomer determined by chiral HPLC

${ }^{\mathrm{d}}$ Opposite enantiomer of the syn product

The $N$-methyl- $\alpha$-methyl compounds $\mathbf{1 7} \mathbf{a}$ and $\mathbf{1 7} \mathbf{b}$ gave very similar overall results to those obtained for the corresponding spirolactams 12a and 12b, with similar diastereocontrol but a slight decrease in enantioselectivity (entries 1 and 2). It is very important to note that the major syn enantiomer $(\mathbf{1 6}(R, S))$ obtained for $\mathbf{1 7 a}$ is opposite to that obtained with the spirolactam 12a (Figure 2). The $\alpha$-methyl $N-\mathrm{H}$ compounds $17 \mathrm{e}$ and $\mathbf{1 7 f}$ showed similar stereoselectivity, but surprisingly much reduced isolated yields of $55 \%$ and $60 \%$. The reason for these reduced yields is not known, at present. These results clearly demonstrate that the presence of a proline $\alpha$ substitutent is detrimental to achieving high levels of stereocontrol. This was borne out when the $\alpha$-hydrogen $N$-Me catalysts $18 \mathrm{c}$ and $18 \mathrm{~d}$ were examined. With the removal of the $\alpha$-methyl substituent the isolated yield was brought back to $94-98 \%$ with excellent diastereoselectivity ( 94:6). Unfortunately, there was no observed increase in enantioselectivity (entries 7 and 8). Finally, the two $N-\mathrm{H}$ catalysts 18 a and 18b were examined and found to give excellent isolated yields, diastereoselectivity and hugely improved enantioselectivity (71 and $81 \%$ e.e.). The diastereoselectivity for these two catalysts are quite different (77:23 and 98:2) and since both contain an $\mathrm{N}-\mathrm{H}$ in the side-chain this difference is likely to be due to the overall conformation of the 
side-chain (entries 5 and 6). Although $\mathbf{1 8 b}$ gave excellent yield and diastereoselectivity results, the enantiomeric excess was $81 \%$, which is below the levels reported for many proline-derived catalysts. ${ }^{3-5}$ For this reason studies on the expansion of the scope of these catalysts in the Michael addition reaction with different aldehydes and substituted $\beta$-nitrostyrenes were not undertaken. The proposed transition state model, involves a steric interaction between the nitro styrene and the amide side-chain on position 2 of the pyrrolidine which destabilises the $R e, R e$ approach for these catalysts (Figure 7), even though there is a favourable electrostatic interaction between the nitro group and the enamine nitrogen. Thus the Si,Si approach predominates where there is a favourable electrostatic interaction between the nitro group and the enamine nitrogen, but no steric interaction with the amide side-chain, thus giving the $R, S$ enantiomer of $\mathbf{1 6}$ as the major enantiomer. The selectivity observed is regardless of whether the side-chain contains an $N-\mathrm{H}$, as a potential hydrogen bond donor for a favourable electrostatic interaction with the nitro group, or whether it is $N$-methylated.

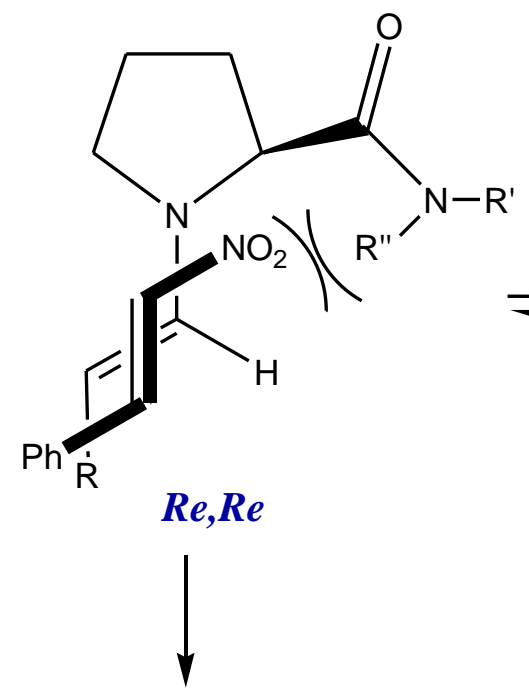

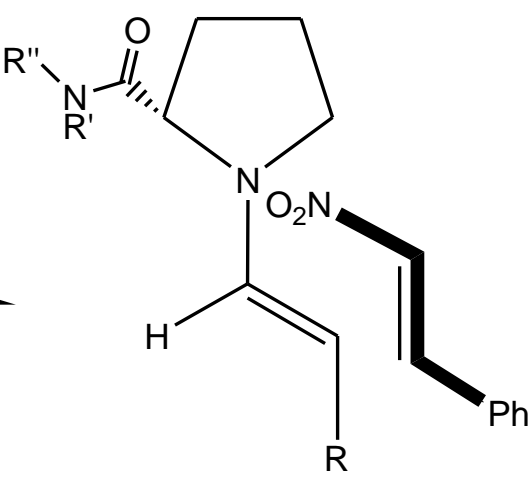

$\mathrm{Si}, \mathrm{Si}$<smiles>CCC[C@@H](C=O)[C@H](C[N+](=O)[O-])c1ccccc1</smiles>

$16(R, S)$

MAJOR

MINOR 
Figure 7. Proposed transition state model for Michael addition reaction of valeraldehyde with $\beta$-nitrostyrene using simple prolinamide catalysts $\mathbf{1 8 a - d}$.

From these studies, it is therefore apparent that the absence of an $\alpha$-substituent and the presence of a sufficiently bulky prolinamide are necessary for the optimal simple prolinamide organocatalyst, for the Michael addition reaction of aldehydes to $\beta$ nitrostyrenes.

\section{Conclusions}

In conclusion, the main advantage of the spirolactam and $\alpha$-methyl prolinamide organocatalysts used in this study is that both epimers of the $\alpha$-centre can be easily synthesised from a common starting material, L-proline. It is thus possible to selectively form either enantiomer of the syn Michael addition product, in excellent yield with good stereocontrol. In the case of other proline-derived catalysts, this would only be possible by separately preparing catalysts starting with D-proline. Furthermore, the amount of catalyst required for activity is low $(5 \mathrm{~mol} \%)$, along with the requirement of only 1.5 molar equivalents of the aldehyde partner. As stated previously the presence of a trans-4-hydroxy substitutent can have a considerable effect on the stereoselectivity obtained and we are also currently preparing analogues of all the synthesised organocatalysts reported here with this functionality present. Further studies on the scope of use of these new organocatalysts in the Michael addition reaction and other important asymmetric transformations are being undertaken, the results of which will be reported in due course.

\section{Experimental.}

TLC was performed on Merck silica gel $60 \mathrm{~F}_{254}$ plates and column chromatography

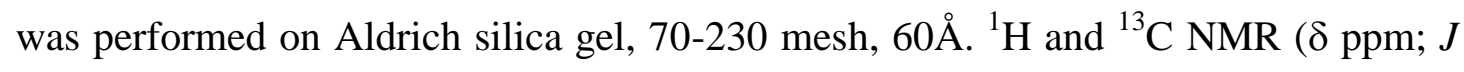
$\mathrm{Hz}$ ) spectra were recorded on a Jeol JNM-LA300 FT-NMR spectrometer using $\mathrm{CDCl}_{3}$ solutions with $\mathrm{Me}_{4} \mathrm{Si}$ as internal reference, unless otherwise indicated, with resolutions of $0.18 \mathrm{~Hz}$ and $0.01 \mathrm{ppm}$, respectively. $\mathrm{CHCl}_{3}$ was used to remove last traces of ethyl acetate from some samples. The last trace of $\mathrm{CHCl}_{3}$ persisted even 
after prolonged heating in vacuo and in these cases was visible in NMR spectra. Infrared spectra $\left(\mathrm{cm}^{-1}\right)$ were recorded as $\mathrm{KBr}$ discs or liquid films between $\mathrm{NaCl}$ plates using a Nicolet Impact 410 FT-IR. Melting points were obtained on a Bibby Stuart Scientific SMP1 melting point apparatus. Microanalyses were carried out at the Microanalytical Laboratory of University College Dublin. High Resolution Mass spectra were obtained in the Centre for Synthesis and Chemical Biology, School of Chemistry and Chemical Biology, University College Dublin. X-ray crystal structures were obtained in the Chemistry Department, Loughborough University, Loughborough, UK. Chiral HPLC analysis were carried out using on a Shimadzu HPLC system Class-VP, incorporating a LC-10AD pump, SPD-M10AVP Diode Array Detector, Auto-injector SIJ-10A with a system controller SCL-10A VP, on Chiralcel OD-H and AD-H chiral columns. Polarimetry was carried out using an Optical Activity AA-55 series polarimeter at ambient temperature with a $2 \mathrm{dm}, 1 \mathrm{ml}$ cell. ( \pm )-2-Methyl-pyrrolidine-1,2-dicarboxylic acid 1-tert-butyl ester (20) is commercially available but was synthesised (vide infra).

\section{$N$-Boc-L-proline methyl ester (19). ${ }^{11}$}

19 was prepared from L-proline by the method of Confalone ${ }^{11}$ giving 19 as a clear oil. Analytical data was in agreement with that reported. Microanalysis: Found C, 57.51; $\mathrm{H}, 8.60 ; \mathrm{N}, 5.88$. Calculated for $\mathrm{C}_{11} \mathrm{H}_{19} \mathrm{NO}_{4}: \mathrm{C}, 57.60 ; \mathrm{H}, 8.34 ; \mathrm{N}, 6.10$.

( \pm )- $\alpha$-Formylmethyl $N$-Boc-proline methyl ester was prepared from 19 as previously described. $^{7 \mathrm{c}}$

(5S) and (5R)-6-Oxo-7-((1'R)-naphthylethyl-)-1,7-diaza-spiro[4.4]nonane-1carboxylic acid tert-butyl ester (14a and 14b).

Prepared from $( \pm$ )- $\alpha$-formylmethyl $N$-Boc-proline methyl ester 19 (0.65 g, $2.4 \mathrm{mmol})$ and (R)-1-(1-naphthyl)ethylamine $(0.35 \mathrm{ml}, 2.50 \mathrm{mmol})$, using the method as previously described for $12 \mathrm{a}$ and $12 \mathrm{~b},{ }^{7 \mathrm{c}}$ giving a yellow oil $(0.75 \mathrm{~g}, 79 \%)$. The oil was purified on silica gel using $20 \%$ ethyl acetate/petroleum ether giving the two diastereoisomers. 
$(S, R)$ Diastereoisomer (14a): Yellow solid, (0.33g, 35\%). $\mathrm{R}_{\mathrm{f}}$ : 0.50 (60\% ethyl acetate: petroleum ether). $[\alpha]_{\mathrm{D}}:+46.66(c=0.75$ in $\mathrm{MeOH})$. M.p.: $153-155{ }^{\circ} \mathrm{C}$. IR, $(\mathrm{KBr}) / \mathrm{cm}^{-1}:$ 3031, 2984, 1685, 1676. ${ }^{1} \mathrm{H}$ NMR (two rotamers present) $\delta: 8.00,7.81$, 7.50, (3 x m, 7H), $6.13(\mathrm{q}, 1 \mathrm{H}, J=7.2 \mathrm{~Hz}), 3.62-3.45(\mathrm{~m}, 3 \mathrm{H}), 3.27 \& 3.08(2 \mathrm{x} \mathrm{t}, 1 \mathrm{H}$, $J=9.0 \mathrm{~Hz}), 2.55-2.30(\mathrm{~m}, 2 \mathrm{H}), 2.15-2.05(\mathrm{~m}, 2 \mathrm{H}), 1.98-1.91(\mathrm{~m}, 2 \mathrm{H}), 1.74(\mathrm{t}, 3 \mathrm{H}, J=$ $7.3 \mathrm{~Hz}), 1.51 \& 1.48(2 \mathrm{x} \mathrm{s}, 9 \mathrm{H}) .{ }^{13} \mathrm{C}$ NMR (two rotamers present) $\delta: 173.2,153.6 \&$ $153.4,137.4,135.6,133.7,128.7,128.5,126.0,124.8,124.1,123.8,123.7,80.2 \&$ 79.4, 67.6 \& 67.5, 48.1 \& 48.0, $46.0 \& 46.2,38.8 \& 38.3,36.8 \& 36.6,30.1 \& 29.8$, 24.7, $23.3 \& 23.1,16.2 \&$ 15.8. HRMS (ESI) calculated for $\mathrm{C}_{24} \mathrm{H}_{31} \mathrm{~N}_{2} \mathrm{O}_{3}[\mathrm{M}+\mathrm{H}]^{+}$: 395.2335. Found: 395.2336.

$(\boldsymbol{R}, \boldsymbol{R})$ Diastereoisomer (14b): Yellow oil, $(0.36 \mathrm{~g}, 38 \%) . \mathrm{R}_{\mathrm{f}}: 0.40$ (60\% ethyl acetate: petroleum ether). $[\alpha]_{\mathrm{D}}:+40.5(c=1$ in $\mathrm{MeOH})$. IR, (Thin film) $/ \mathrm{cm}^{-1}: 3031,2986$, 1680, 1676. ${ }^{1} \mathrm{H}$ NMR (two rotamers present) $\delta: 8.61(\mathrm{~d}, 1 \mathrm{H}, J=8.2 \mathrm{~Hz}), 8.20(\mathrm{~d}, 1 \mathrm{H}$, $J=8.3 \mathrm{~Hz}), 7.81 \& 7.50,(2 \mathrm{x} \mathrm{m}, 6 \mathrm{H}),, 6.27(\mathrm{q}, 0.5 \mathrm{H}, J=6.8 \mathrm{~Hz}), 6.06(\mathrm{q}, 0.5 \mathrm{H}, J=$ $6.8 \mathrm{~Hz}), 3.69-3.42(\mathrm{~m}, 2 \mathrm{H}), 3.28(\mathrm{~m}, 1 \mathrm{H}), 3.12-2.90(\mathrm{~m}, 1 \mathrm{H}), 2.69(\mathrm{t}, 1 \mathrm{H}, J=7.0 \mathrm{~Hz})$, 2.41-1.67 (m, 5H), $1.63(\mathrm{~d}, 3 \mathrm{H}, J=7.0 \mathrm{~Hz}), 1.45(\mathrm{~s}, 9 \mathrm{H}) .{ }^{13} \mathrm{C}$ NMR (two rotamers present) $\delta: 173.5,153.6,136.5,135.8,133.2,128.6,128.2,126.1,125.0,124.4$, $123.9,123.8,79.8 \& 79.4,68.0 \& 67.8,48.3 \& 48.1,46.5 \& 46.2,38.7 \& 38.5,37.1$ \& 36.8, $29.9 \& 29.8,28.6,22.6 \& 22.2,16.4 \& 16.1$. HRMS (ESI) calculated for $\mathrm{C}_{24} \mathrm{H}_{31} \mathrm{~N}_{2} \mathrm{O}_{3}[\mathrm{M}+\mathrm{H}]^{+}:$395.2335. Found: 395.2328.

\section{(5S)-6-Oxo-7-((1'R)-naphthylethyl-)-1,7-diaza-spiro[4.4]nonane (15a)}

To a solution of 14a $(0.145 \mathrm{~g}, 0.42 \mathrm{mmol})$ in DCM $(0.3 \mathrm{ml})$ was added TFA $(0.3 \mathrm{ml}$, $1.28 \mathrm{mmol}$ ), and then stirred at ambient temperature for $16 \mathrm{hr}$. The solution was then concentrated in vacuo, dissolved in $\mathrm{H}_{2} \mathrm{O}(40 \mathrm{ml})$, and the $\mathrm{pH}$ adjusted to $\sim 8$ by adding $\mathrm{Et}_{3} \mathrm{~N}$ dropwise, at $0{ }^{\circ} \mathrm{C}$. The product was then extracted with DCM (3 x $\left.20 \mathrm{ml}\right)$, dried over $\mathrm{MgSO}_{4}$, and concentrated in vacuo yielding an oil, which was purified on silica gel using 5\% MeOH:DCM, giving the product.

$(\boldsymbol{S}, \boldsymbol{R})$ Diastereoisomer (15a): yellow oil (0.77g, 90\%). $\mathrm{R}_{\mathrm{f}}: 0.5$ (10\% MeOH: DCM). $[\alpha]_{\mathrm{D}}:+8.2(c=1.1$ in $\mathrm{MeOH}) . \mathrm{IR}$, (Thin film) $/ \mathrm{cm}^{-1}: 3332,3032,2995,1684 .{ }^{1} \mathrm{H}$ NMR $\delta: 7.99-7.96(\mathrm{~m}, 1 \mathrm{H}), 7.88-7.81(\mathrm{~m}, 2 \mathrm{H}), 7.56-7.44(\mathrm{~m}, 4 \mathrm{H}), 6.10(\mathrm{q}, 1 \mathrm{H}, J=$ 7.0 Hz), 3.27-3.22 (m, 1H), 3.12-3.05 (m, 1H), 2.98-2.90 (m, 1H), 2.28-2.22 (m, 1H), 
1.71-1.93 (m, 7H), $1.68(\mathrm{~d}, 3 \mathrm{H}, J=7.1 \mathrm{~Hz}) .{ }^{13} \mathrm{C}$ NMR $\delta: 176.0,135.1,133.7,131.6$, 128.7, 128.6, 128.3, 126.8, 124.9, 124.1, 123.4, 68.1, 47.5, 46.1, 39.1, 35.3, 34.8, 26.0, 16.1. HRMS (ESI) calculated for $\mathrm{C}_{19} \mathrm{H}_{23} \mathrm{~N}_{2} \mathrm{O}[\mathrm{M}+\mathrm{H}]^{+}:$295.1810. Found: 295.1801.

(5R)-6-Oxo-7-((1'R)-naphthylethyl-)-1,7-diaza-spiro[4.4]nonane (15b)

Was prepared from $\mathbf{1 4 b}$ in a similar manner to the preparation of $\mathbf{1 5 a}$.

$(\boldsymbol{R}, \boldsymbol{R})$ Diastereoisomer (15b): yellow oil (0.78g, 92\%). $\mathrm{R}_{\mathrm{f}}: 0.3$ (10\% MeOH: DCM), $[\alpha]_{\mathrm{D}}:+11.0(c=1$ in MeOH$)$. IR, (Thin film) $/ \mathrm{cm}^{-1}: 3335,3030,2994,1685 .{ }^{1} \mathrm{H}$ NMR $\delta:$ 8.10-8.01 (m, 0.5H), 7.87-7.81 (m, 0.5H), 7.55-7.48 (m, 2H), 7.46-7.21 (m, $4 \mathrm{H}), 6.14(\mathrm{q}, 1 \mathrm{H}, J=7.0 \mathrm{~Hz}), 3.28-3.22(\mathrm{~m}, 1 \mathrm{H}), 3.18-3.05(\mathrm{~m}, 1 \mathrm{H}), 2.98-2.91(\mathrm{~m}$, $1 \mathrm{H}), 2.56-2.45(\mathrm{~m}, 1 \mathrm{H}), 2.14-1.68(\mathrm{~m}, 7 \mathrm{H}), 1.60(\mathrm{~d}, 3 \mathrm{H}, J=7.1 \mathrm{~Hz}) .{ }^{13} \mathrm{C} \mathrm{NMR} \delta$ : 176.1, 135.1, 133.8, 131.5, 128.8, 128.6, 128.4, 126.8, 125.0, 124.2, 123.6, 68.4, 47.3, 46.2, 39.1, 35.2, 34.3, 25.8, 16.3. HRMS (ESI) calculated for $\mathrm{C}_{19} \mathrm{H}_{23} \mathrm{~N}_{2} \mathrm{O}[\mathrm{M}+\mathrm{H}]^{+}$: 295.1810. Found: 295.1802 .

\section{( \pm )-2-Methyl-pyrrolidine-1,2-dicarboxylic acid 1-tert-butyl ester 2-methyl ester} (20)

To a solution of $19(0.5 \mathrm{~g}, 2.18 \mathrm{mmol})$ in dry THF $(2 \mathrm{ml})$ at $-20{ }^{\circ} \mathrm{C}$, was added a $1.0 \mathrm{M}$ solution of LiHMDS in THF (3.1 ml, $3.1 \mathrm{mmol})$ slowly while keeping the temperature below $-15^{\circ} \mathrm{C}$. The solution was stirred for $1.5 \mathrm{hr}$, under nitrogen, at this temperature. Methyl iodide $(0.25 \mathrm{ml}, 3.1 \mathrm{mmol})$ was added slowly at $-20{ }^{\circ} \mathrm{C}$. The solution was stirred while allowing it to warm to ambient temperature. After $18 \mathrm{hr}$ the solution was quenched with a saturated aqueous solution of $\mathrm{NH}_{4} \mathrm{Cl}(5 \mathrm{ml})$, extracted with ethyl acetate $(3 \times 20 \mathrm{ml})$, washed with a brine solution $(3 \times 10 \mathrm{ml})$ and then dried over $\mathrm{MgSO}_{4}$. The resulting solution was concentrated in vacuo and was purified by column chromatography on silica gel, using $10 \%$ ethyl acetate: petroleum ether, giving a colourless oil (0.38 g, $72 \%)$. $\mathrm{R}_{\mathrm{f}}: 0.50$ (20\% ethyl acetate: petroleum ether). IR, (Thin film) $/ \mathrm{cm}^{-1}: 2975,1750,1692,1418 .{ }^{1} \mathrm{H}$ NMR (two rotamers present) $\delta: 3.75$ (s, 3H), 3.70-3.64 (m, 1H), 3.62-3.43 (m, 1H), 2.23-2.05 (m, 1H), 2.04-1.92 (m, 3H), $1.58(\mathrm{~s}$, $3 \mathrm{H}), 1.45 \& 1.41(2 \mathrm{x} \mathrm{s}, 9 \mathrm{H}) .{ }^{13} \mathrm{C}$ NMR (two rotamers present) $\delta: 175.4,153.6,79.9$, 64.8, 52.1, 47.9, 40.1, 28.2, 23.1, 22.3. 
( \pm )-2-Methyl-pyrrolidine-1,2-dicarboxylic acid 1-tert-butyl ester (21)

A suspension of $20(1.25 \mathrm{~g}, 5.14 \mathrm{mmol})$ and $\mathrm{NaOH}(0.204 \mathrm{~g}, 5.1 \mathrm{mmol})$ in $\mathrm{MeOH} / \mathrm{H}_{2} \mathrm{O}(1: 1,20 \mathrm{ml})$ was heated at reflux temperature for $5 \mathrm{hr}$. The solvent was removed in vacuo, and the residue was partitioned between diethyl ether and $\mathrm{H}_{2} \mathrm{O}$ $(1: 1,20 \mathrm{ml})$. The aqueous phase was then washed with diethyl ether $(3 \times 10 \mathrm{ml})$, acidified to $\mathrm{pH} 3$ using $1 \mathrm{~N} \mathrm{HCl}$, followed by extraction with diethyl ether. The ether layer was then dried over $\mathrm{MgSO}_{4}$ and concentrated in vacuo yielding the product $(1.10 \mathrm{~g}, 93 \%)$, which was used without further purification. $\mathrm{R}_{\mathrm{f}}$ : 0.10 (20\% ethyl acetate: petroleum ether). M.p.: 91-94 ${ }^{\circ} \mathrm{C}$. IR, (Thin film)/ $\mathrm{cm}^{-1}$ : 2978, 1740, 1648, 1432. ${ }^{1} \mathrm{H}$ NMR (two rotamers present) $\delta: 3.62-3.42(\mathrm{~m}, 2 \mathrm{H}), 2.60(\mathrm{~m}, 1 \mathrm{H}), 2.45 \&$ $2.28(2 \times \mathrm{m}, 1 \mathrm{H}), 1.95-1.77(\mathrm{~m}, 2 \mathrm{H}), 1.62(\mathrm{~s}, 3 \mathrm{H}), 1.48 \& 1.42(2 \mathrm{x} \mathrm{s}, 9 \mathrm{H}) .{ }^{13} \mathrm{C} \mathrm{NMR}$ (two rotamers present) $\delta$ : $176.5,152.3,80.6,66.8,48.7,38.4,28.4,22.8,22.2$.

2-Methyl-2-[methyl-(1-phenylethyl)-carbamoyl]-pyrrolidine-1-carboxylic acid tert-butyl ester (22a and $22 b)$.

To a stirred solution of 21 (0.45 g, $1.96 \mathrm{mmol})$ in dry DMF $(9 \mathrm{ml})$ was added DIPEA $(0.675 \mathrm{ml}, 3.92 \mathrm{mmol})$, followed by $(R)-N$-methyl- $\alpha$-methylbenzyl amine $(0.25 \mathrm{ml}$, $1.96 \mathrm{mmol}$ ) dropwise. After stirring for $5 \mathrm{~min}$. the solution was cooled to $0{ }^{\circ} \mathrm{C}$, and a solution of HATU $(0.752 \mathrm{~g}, 1.98 \mathrm{mmol})$ in dry DMF $(9 \mathrm{ml})$ was added slowly. After $10 \mathrm{~min}$ at this temperature, the solution was allowed to warm to ambient temperature and stirring was continued for $4 \mathrm{hr}$. The solution was diluted with EtOAc $(200 \mathrm{ml})$, and then washed successively with $10 \% \mathrm{HCl}$ solution $(3 \times 10 \mathrm{ml})$, saturated aqueous sodium carbonate solution $(3 \times 10 \mathrm{ml}), \mathrm{H}_{2} \mathrm{O}(3 \times 10 \mathrm{ml})$ and brine solution $(3 \times 10$ $\mathrm{ml}$ ), and then dried over $\mathrm{MgSO}_{4}$. The solution was concentrated in vacuo giving the crude product $(0.65 \mathrm{~g})$ which was purified by column chromatography on silica gel in $10 \%$ ethyl acetate: petroleum ether.

$(\boldsymbol{S}, \boldsymbol{R})$ Diastereoisomer (22a): Colourless oil, (0.12 g, $18 \%) . \mathrm{R}_{\mathrm{f}}: 0.7$ (40\% ethyl acetate: petroleum ether). $[\alpha]_{\mathrm{D}}:+8.18(c=0.55 \mathrm{in} \mathrm{MeOH})$. IR, (Thin film) $/ \mathrm{cm}^{-1}$ : 2976, 1686, 1678. ${ }^{1} \mathrm{H}$ NMR (two rotamers present) $\delta$ : 7.36-7.24 (m, 5H), 6.18-6.11 (m, 1H), 3.75-3.63 \& 3.60-3.52 (2 x m, 1H), 3.38-3.30 (m, 1H), $2.61 \& 2.56(2 \times \mathrm{s}$, $3 \mathrm{H}), 2.16-1.96(\mathrm{~m}, 4 \mathrm{H}), 1.59(\mathrm{~s}, 3 \mathrm{H}), 1.56 \& 1.52(2 \mathrm{x} \mathrm{s}, 3 \mathrm{H}), 1.48(\mathrm{~s}, 9 \mathrm{H}) .{ }^{13} \mathrm{C} \mathrm{NMR}$ (two rotamers present) $\delta: 173.0,153.5,141.3,128.5,127.1 \& 126.8,80.3,66.2,51.7$, 
46.7, 38.1, 29.7, 28.3, 24.7, 23.8, 22.1. HRMS (ESI) calculated for $\mathrm{C}_{19} \mathrm{H}_{29} \mathrm{~N}_{2} \mathrm{O}_{3}$ $[\mathrm{M}+\mathrm{H}]^{+}:$347.2335. Found: 347.2318.

$(\boldsymbol{R}, \boldsymbol{R})$ Diastereoisomer (22b): Colourless oil, $(0.21 \mathrm{~g}, 31 \%) . \mathrm{R}_{\mathrm{f}}: 0.6$ (40\% ethyl acetate: petroleum ether). $[\alpha]_{\mathrm{D}}:+23.9(c=0.67 \mathrm{in} \mathrm{MeOH})$. IR, (Thin film) $/ \mathrm{cm}^{-1}$ : 2972, 1680, 1678. ${ }^{1} \mathrm{H}$ NMR (two rotamers present) $\delta: 7.40-7.26(\mathrm{~m}, 5 \mathrm{H}), 6.21-6.09$ (m, 1H), 3.78-3.62 \& 3.59-3.51 $(2 \times \mathrm{m}, 1 \mathrm{H}), 3.36-3.23(\mathrm{~m}, 1 \mathrm{H}), 2.65 \& 2.50(2 \times \mathrm{s}$, $3 \mathrm{H}), 2.25-1.92(\mathrm{~m}, 4 \mathrm{H}), 1.59 \& 1.57(2 \mathrm{x} \mathrm{s}, 3 \mathrm{H}), 1.51 \& 1.42(2 \mathrm{x} \mathrm{d}, J=1.1 \mathrm{~Hz}, 3 \mathrm{H}$, $\mathrm{H}), 1.25 \& 1.19(2 \times \mathrm{s}, 9 \mathrm{H}) .{ }^{13} \mathrm{C}$ NMR (two rotamers present) $\delta: 172.8,153.1,141.6$, $141.4,128.6,127.2 \& 126.9,80.1,66.0,51.9,47.2 \& 47.0,38.6 \& 38.2,29.6 \& 29.4$, 28.7, $24.7 \& 24.5,23.8 \& 23.6,22.1 \& 21.8$. HRMS (ESI) calculated for $\mathrm{C}_{19} \mathrm{H}_{29} \mathrm{~N}_{2} \mathrm{O}_{3}$ $[\mathrm{M}+\mathrm{H}]^{+}:$347.2335. Found: 347.2325.

The reaction was then conducted using $(S)-N$-methylbenzyl amine, following the method previously described, forming the $(\boldsymbol{R}, \boldsymbol{S})$ and $(\boldsymbol{S}, \boldsymbol{S})$ diastereoisomers $22 \mathrm{c}$ and 22d.

$(\boldsymbol{R}, \boldsymbol{S})$ Diastereoisomer (22c): Colourless oil, $(0.13 \mathrm{~g}, 19 \%) .[\alpha]_{\mathrm{D}}:-8.2(c=0.55$ in $\mathrm{MeOH})$. Analytical data is identical to that of the $(\boldsymbol{S}, \boldsymbol{R})$ diastereoisomer. HRMS (ESI) calculated for $\mathrm{C}_{19} \mathrm{H}_{29} \mathrm{~N}_{2} \mathrm{O}_{3}[\mathrm{M}+\mathrm{H}]^{+}: 347.2335$. Found: 347.2320.

$(\mathbf{S}, \boldsymbol{S})$ Diastereoisomer (22d): Colourless oil, $(0.24 \mathrm{~g}, 35 \%)$. $[\alpha]_{\mathrm{D}}:-24(c=0.7$ in $\mathrm{MeOH})$. Analytical data is identical to that of the $(\boldsymbol{R}, \boldsymbol{R})$ diastereoisomer. HRMS (ESI) calculated for $\mathrm{C}_{19} \mathrm{H}_{29} \mathrm{~N}_{2} \mathrm{O}_{3}[\mathrm{M}+\mathrm{H}]^{+}$: 347.2335. Found: 347.2335.

\section{2-Methyl-pyrrolidine-2-carboxylic acid methyl-(1-phenyl-ethyl)-amide (17a-d).}

To a solution of $22(\mathbf{a}-\mathbf{d})(0.145 \mathrm{~g}, 0.42 \mathrm{mmol})$ in DCM $(0.3 \mathrm{ml})$ was added TFA $(0.3$ $\mathrm{ml}, 1.28 \mathrm{mmol}$ ), and it was stirred at ambient temperature for $16 \mathrm{hr}$. It was then concentrated in vacuo, dissolved in $\mathrm{H}_{2} \mathrm{O}(40 \mathrm{ml})$, and the $\mathrm{pH}$ was adjusted to $\sim 8$ by adding $\mathrm{Et}_{3} \mathrm{~N}$ dropwise, at $0{ }^{\circ} \mathrm{C}$. It was then extracted with DCM $(3 \times 20 \mathrm{ml})$, dried over $\mathrm{MgSO}_{4}$, and concentrated in vacuo yielding an oil, which was purified on silica gel using 5\% MeOH:DCM. 
(S,R) Diastereoisomer (17a): Colourless oil, (0.09 g, $88 \%)$.

$\mathrm{R}_{\mathrm{f}}: 0.6(10 \% \mathrm{MeOH}: \mathrm{DCM}) \cdot[\alpha]_{\mathrm{D}}:+18\left(c=1\right.$ in MeOH). IR, (Thin film) $/ \mathrm{cm}^{-1}$ : 3276, 2974, 1676. ${ }^{1} \mathrm{H}$ NMR (two rotamers present) $\delta:$ 7.40-7.22 (m, 5H), $6.04 \& 5.35$ ( 2 x q, $J=7.0 \mathrm{~Hz}, 1 \mathrm{H}), 3.47-3.41 \& 3.11-3.02$ ( 2 x m, 2H), 2.74 (s, 3H), 2.30-1.95 $(\mathrm{m}, 4 \mathrm{H}), 1.75 \& 1.70(2 \times \mathrm{s}, 3 \mathrm{H}), 1.53(\mathrm{~d}, J=7.1 \mathrm{~Hz}, 3 \mathrm{H}) .{ }^{13} \mathrm{C}$ NMR (two rotamers present) $\delta: 172.8,139.4,129.0,127.7 \& 127.1,68.3,52.7,45.6,36.2,30.4,25.6,23.9$, 15.2. HRMS (ESI) calculated for $\mathrm{C}_{15} \mathrm{H}_{23} \mathrm{~N}_{2} \mathrm{O}[\mathrm{M}+\mathrm{H}]^{+}$: 247.1810. Found: 247.1821 .

$(\boldsymbol{R}, \boldsymbol{R})$ Diastereoisomer (17b): Colourless oil, (0.092 g, $89 \%) . \mathrm{R}_{\mathrm{f}}: 0.5(10 \% \mathrm{MeOH}:$ DCM). $[\alpha]_{\mathrm{D}}:+25\left(c=1\right.$ in MeOH). IR, (Thin film) $/ \mathrm{cm}^{-1}: 3270,2976,1674 .{ }^{1} \mathrm{H}$ NMR (two rotamers present) $\delta: 7.36-7.23(\mathrm{~m}, 5 \mathrm{H}), 6.06 \& 5.56(2 \mathrm{x} \mathrm{q}, J=7.1 \mathrm{~Hz}$, $1 \mathrm{H}), 3.26-3.20 \& 3.01-2.92(2 \times \mathrm{m}, 2 \mathrm{H}), 2.76 \& 2.70(2 \times \mathrm{s}, 3 \mathrm{H}), 2.17-1.83(\mathrm{~m}, 4 \mathrm{H})$, $1.59(\mathrm{~s}, 3 \mathrm{H}), 1.51(\mathrm{~d}, J=7.0 \mathrm{~Hz}, 3 \mathrm{H}) .{ }^{13} \mathrm{C}$ NMR (two rotamers present) $\delta$ : 174.7, $130.1,128.6,127.4 \& 126.3,66.9,52.3,46.2$, 36.6, 30.4, 26.0, 25.6, 15.2. HRMS (ESI) calculated for $\mathrm{C}_{15} \mathrm{H}_{23} \mathrm{~N}_{2} \mathrm{O}[\mathrm{M}+\mathrm{H}]^{+}:$247.1810. Found: 247.1810 .

$(\boldsymbol{R}, \boldsymbol{S})$ Diastereoisomer (17c): Colourless oil, $(0.095 \mathrm{~g}, 92 \%)$. [ $\alpha]_{\mathrm{D}}:-18(c=1$ in $\mathrm{MeOH})$. Analytical data is identical to that of the $(\boldsymbol{S}, \boldsymbol{R})$ diastereoisomer. HRMS (ESI) calculated for $\mathrm{C}_{15} \mathrm{H}_{23} \mathrm{~N}_{2} \mathrm{O}[\mathrm{M}+\mathrm{H}]^{+}$: 247.1810. Found: 247.1821.

(S,S) Diastereoisomer (17d): Colourless oil, $(0.095 \mathrm{~g}, 92 \%) .[\alpha]_{\mathrm{D}}:-26(c=1$ in $\mathrm{MeOH})$. Analytical data is identical to that of the $(\boldsymbol{R}, \boldsymbol{R})$ diastereoisomer. HRMS (ESI) calculated for $\mathrm{C}_{15} \mathrm{H}_{23} \mathrm{~N}_{2} \mathrm{O}[\mathrm{M}+\mathrm{H}]^{+}:$247.1810. Found: 247.1808 .

\section{2-Methyl-2-(1-phenyl-ethylcarbamoyl)-pyrrolidine-1-carboxylic acid tert-butyl ester $(22 \mathrm{e}-\mathrm{h})$.}

To a stirred solution of $21(0.50 \mathrm{~g}, 2.18 \mathrm{mmol})$ in dry DMF $(10 \mathrm{ml})$ was added DIPEA $(0.75 \mathrm{ml}, 4.36 \mathrm{mmol})$, followed by $(R)-1$-phenylethylamine $(0.29 \mathrm{ml}, 2.18 \mathrm{mmol})$ dropwise. After $5 \mathrm{~min}$ stirring, the solution was cooled to $0{ }^{\circ} \mathrm{C}$, and a solution of HATU $(0.84 \mathrm{~g}, 2.2 \mathrm{mmol})$ in dry DMF (10 ml) was added slowly. After $10 \mathrm{~min}$ at this temperature, the solution was allowed to warm to ambient temperature and stirring was continued for $3 \mathrm{hr}$. The solution was diluted with EtOAc $(200 \mathrm{ml})$, and then washed successively with $10 \% \mathrm{HCl}(3 \times 10 \mathrm{ml})$, saturated aqueous sodium carbonate 
solution $(3 \times 10 \mathrm{ml}), \mathrm{H}_{2} \mathrm{O}(3 \times 10 \mathrm{ml})$ and brine solution $(3 \times 10 \mathrm{ml})$, and then dried over $\mathrm{MgSO}_{4}$. The solution was concentrated in vacuo yielding a colourless oil (0.70 $\mathrm{g}$ ), which was purified by column chromatography on silica gel in $10 \%$ ethyl acetate: petroleum ether.

$(\boldsymbol{S}, \boldsymbol{R})$ Diastereoisomer (22e): White solid, (0.38 g, $52 \%) . \mathrm{R}_{\mathrm{f}}$ : 0.70 (40\% ethyl acetate: petroleum ether). M.p.: $129-132{ }^{\circ} \mathrm{C} .[\alpha]_{\mathrm{D}}:-18.6(c=0.7$ in $\mathrm{MeOH}) . \mathrm{IR}$, $(\mathrm{KBr}) / \mathrm{cm}^{-1}: 3305,2976,1682,1671 .{ }^{1} \mathrm{H}$ NMR $\delta: 7.82(\mathrm{~s}(\mathrm{br}), 1 \mathrm{H}), 7.32-7.26(\mathrm{~m}, 5 \mathrm{H})$, 5.07 (s(br), 1H), 3.52-3.25 (m(br), 2H), 2.68-2.62 (m(br), 1H), 2.19-2.15 (m(br), 1H), 1.67-1.70 (m(br), 2H), 1.57 (m(br), 6H), 1.47 (s, 9H). ${ }^{13} \mathrm{C}$ NMR $\delta: 173.7,152.5$, 129.2, 128.2, 127.1, 48.2, 28.5, 22.4, 18.4. HRMS (ESI) calculated for $\mathrm{C}_{19} \mathrm{H}_{29} \mathrm{~N}_{2} \mathrm{O}_{3}$ $[\mathrm{M}+\mathrm{H}]^{+}:$333.2178. Found: 333.2174 .

$(\boldsymbol{R}, \boldsymbol{R})$ Diastereoisomer (22f): Colourless oil, (0.30 g, $42 \%) . \mathrm{R}_{\mathrm{f}}: 0.60$ (40\% ethyl acetate: petroleum ether). $[\alpha]_{\mathrm{D}}:+3.8(c=0.5 \mathrm{in} \mathrm{MeOH})$. IR, (Thin film) $/ \mathrm{cm}^{-1}: 3308$, 2972, 1684, 1672. ${ }^{1} \mathrm{H}$ NMR $\delta: 7.78$ (s(br), 1H) 7.33-7.28 (m, 5H), 5.08 (m(br), 1H), $3.53(\mathrm{~m}(\mathrm{br}), 2 \mathrm{H}), 2.66(\mathrm{~m}(\mathrm{br}), 1 \mathrm{H}), 2.28(\mathrm{~m}(\mathrm{br}), 1 \mathrm{H}), 1.79$ (m(br), 2H), 1.58 (m(br),

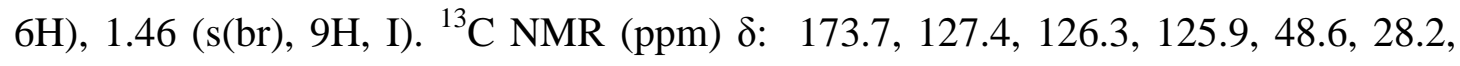
23.4, 22.6. HRMS (ESI) calculated for $\mathrm{C}_{19} \mathrm{H}_{29} \mathrm{~N}_{2} \mathrm{O}_{3}[\mathrm{M}+\mathrm{H}]^{+}$: 333.2178. Found: 333.2193.

The reaction was then conducted using (S)-(1)-phenylethyl amine, following the method previously described, forming the $(\boldsymbol{R}, \boldsymbol{S})$ and $(\boldsymbol{S}, \boldsymbol{S})$ diastereoisomers.

(R,S) Diastereoisomer (22g): White solid, (0.38 g, $52 \%)$. M.p.: $128-131{ }^{\circ} \mathrm{C} .[\alpha]_{\mathrm{D}}$ : $+18.5(c=0.7$ in $\mathrm{MeOH})$. Other analytical data is identical to that of 22e. HRMS (ESI) calculated for $\mathrm{C}_{19} \mathrm{H}_{29} \mathrm{~N}_{2} \mathrm{O}_{3}[\mathrm{M}+\mathrm{H}]^{+}$: 333.2178. Found: 333.2192.

$(\boldsymbol{S}, \boldsymbol{S})$ Diastereoisomer (22h): Colourless oil, $(0.30 \mathrm{~g}, 42 \%) .[\alpha]_{\mathrm{D}}:-4.0(c=0.5 \mathrm{in}$ $\mathrm{MeOH}$ ). Other analytical data is identical to that of 22f. HRMS (ESI) calculated for $\mathrm{C}_{19} \mathrm{H}_{29} \mathrm{~N}_{2} \mathrm{O}_{3}[\mathrm{M}+\mathrm{H}]^{+}$: 333.2178. Found: 333.2180. 
To a solution of $22(\mathbf{e}-\mathbf{h})(0.2 \mathrm{~g}, 0.602 \mathrm{mmol})$ in DCM $(0.4 \mathrm{ml})$ was added TFA $(0.4$ $\mathrm{ml}, 1.7 \mathrm{mmol}$ ), and then stirred at ambient temperature for $16 \mathrm{hr}$. The solution was then concentrated in vacuo, dissolved in $\mathrm{H}_{2} \mathrm{O}(40 \mathrm{ml})$, and the $\mathrm{pH}$ adjusted to $\sim 8$ by adding $\mathrm{Et}_{3} \mathrm{~N}$ dropwise, at $0{ }^{\circ} \mathrm{C}$. It was then extracted with DCM (3 x $\left.20 \mathrm{ml}\right)$, dried over $\mathrm{MgSO}_{4}$, and concentrated in vacuo yielding an oil, which was purified on silica gel in 5\% MeOH:DCM.

$(\boldsymbol{S}, \boldsymbol{R})$ Diastereoisomer (17e): Yellow solid, (0.14 g, $96 \%) . \mathrm{R}_{\mathrm{f}}: 0.2(5 \% \mathrm{MeOH}:$ DCM). M.p.: $100-103{ }^{\circ} \mathrm{C} .[\alpha]_{\mathrm{D}}:+30.5(c=1$ in $\mathrm{MeOH})$. IR, $(\mathrm{KBr}) / \mathrm{cm}^{-1}: 3414,3270$, 2974, 1673. ${ }^{1} \mathrm{H}$ NMR $\delta: 8.25$ (br. s, $\left.1 \mathrm{H}\right), 7.35-7.21$ (m, 5H), 5.04 (q, $\left.J=7.1 \mathrm{~Hz}, 1 \mathrm{H}\right)$, 3.08-3.03 \& 2.83-2.76 (2 x m, 2H), 2.23-2.17 (m, 1H), 1.71-1.53 (m, 3H), 1.46 (d, $J=$ $6.9 \mathrm{~Hz}, 3 \mathrm{H}), 1.43$ (s, 3H). ${ }^{13} \mathrm{C}$ NMR $\delta$ : 178.0, 144.0, 128.5, 126.9, 125.9, 66.6, 48.1, 47.4, 37.6, 26.5, 25.9, 22.3. HRMS (ESI) calculated for $\mathrm{C}_{14} \mathrm{H}_{21} \mathrm{~N}_{2} \mathrm{O}[\mathrm{M}+\mathrm{H}]^{+}$: 233.1654. Found: 233.1649.

$(\boldsymbol{R}, \boldsymbol{R})$ Diastereoisomer (17f): Yellow oil, $(0.13 \mathrm{~g}, 93 \%) . \mathrm{R}_{\mathrm{f}}: 0.2(5 \% \mathrm{MeOH}:$ DCM). $[\alpha]_{\mathrm{D}}^{20}:+95\left(c=1\right.$ in MeOH). IR, (Thin film) $/ \mathrm{cm}^{-1}: 3416,3272,2976,1674$. ${ }^{1} \mathrm{H}$ NMR $\delta: 8.12$ (s (br), 1H), 7.36-7.22 (m, 5H), 5.03 (q, $\left.J=6.9 \mathrm{~Hz}, 1 \mathrm{H}\right), 3.21-3.12$ \& 2.96-2.88 (2 x m, 2H), 2.32-2.26 (m, 1H), 1.84-1.63 (m, 3H), 1.47 (d, J = 7.0 Hz, $3 \mathrm{H}), 1.44$ (s, 3H). ${ }^{13} \mathrm{C}$ NMR $\delta: 175.3,146.4,128.6,127.2,126.0,67.1,48.5,46.8$, 37.4, 28.5, 26.1, 22.8. HRMS (ESI) calculated for $\mathrm{C}_{14} \mathrm{H}_{21} \mathrm{~N}_{2} \mathrm{O}[\mathrm{M}+\mathrm{H}]^{+}$: 233.1654. Found: 233.1660.

$(\boldsymbol{R}, \boldsymbol{S})$ Diastereoisomer (17g): Yellow solid, $(0.133$ g, $95 \%)$._M.p.: 106-109 ${ }^{\circ}$ C. $[\alpha]_{\mathrm{D}}$ : - $30.5(c=1$ in $\mathrm{MeOH})$. Other analytical data is identical to that of $17 \mathrm{e}$ diastereoisomer. HRMS (ESI) calculated for $\mathrm{C}_{14} \mathrm{H}_{21} \mathrm{~N}_{2} \mathrm{O}[\mathrm{M}+\mathrm{H}]^{+}:$233.1654. Found: 233.1652 .

(S,S) Diastereoisomer (17h): Yellow oil, (0.133 g, $95 \%) . \mathrm{R}_{\mathrm{f}}: 0.2(5 \% \mathrm{MeOH}:$ DCM). $[\alpha]_{\mathrm{D}}:-81(c=1 \%, l=2 \mathrm{dm}, \mathrm{MeOH})$. Other analytical data is identical to that of $17 f$ diastereoisomer. HRMS (ESI) calculated for $\mathrm{C}_{14} \mathrm{H}_{21} \mathrm{~N}_{2} \mathrm{O}[\mathrm{M}+\mathrm{H}]^{+}$: 233.1654. Found: 233.1647.

Pyrrolidine-1,2-dicarboxylic acid 1-tert-butyl ester (23) 
A suspension of N-Boc-L-proline methyl $\operatorname{ester}^{7 \mathrm{c}}(1.25 \mathrm{~g}, 5.45 \mathrm{mmol})$ and $\mathrm{NaOH}$ $(0.216 \mathrm{~g}, 5.4 \mathrm{mmol})$ in $\mathrm{MeOH} / \mathrm{H}_{2} \mathrm{O}(1: 1,20 \mathrm{ml})$ was heated at reflux temperature for 5 hr. The solvent was removed in vacuo, and the residue was dissolved partitioned between diethyl ether and $\mathrm{H}_{2} \mathrm{O}(1: 1,20 \mathrm{ml})$. The aqueous phase was then washed with diethyl ether $(3 \times 10 \mathrm{ml})$, acidified to $\mathrm{pH} \sim 3$ using $1 \mathrm{~N} \mathrm{HCl}$, and extracted with diethyl ether $(20 \mathrm{ml})$. The ether layer was then dried over $\mathrm{MgSO}_{4}$ and concentrated in vacuo giving the product as a white solid $(1.15 \mathrm{~g}, 98 \%)$. It was used without further purification. $\mathrm{R}_{\mathrm{f}}$ : 0.1 (20\% ethyl acetate: petroleum ether). M.p.: $133-136{ }^{\circ} \mathrm{C}$. IR, $(\mathrm{KBr}) / \mathrm{cm}^{-1}: 2976,1739,1639,1431 .{ }^{1} \mathrm{H}$ NMR (two rotamers present) $\delta:$ 4.36-4.25 $(\mathrm{m}, 1 \mathrm{H}), 3.52-3.33(\mathrm{~m}, 2 \mathrm{H}), 2.40-2.27(\mathrm{~m}, 1 \mathrm{H}), 2.18-1.88(\mathrm{~m}, 3 \mathrm{H}), 1.50 \& 1.43(2 \mathrm{x} \mathrm{s}$, 9H). ${ }^{13} \mathrm{C}$ NMR (ppm) $\delta: 177.1,156.7,79.8,67.2,47.2,28.3,28.1,23.7$.

\section{S-(1'R-Phenyl-ethylcarbamoyl)-pyrrolidine-1-carboxylic acid tert-butyl ester} (24a)

To a stirred solution of $23(0.32 \mathrm{~g}, 1.50 \mathrm{mmol})$ in dry DCM (5 ml) was added $(R)-1$ phenylethylamine $(0.17 \mathrm{ml}, 1.50 \mathrm{mmol})$ dropwise, followed by DMAP $(0.183 \mathrm{~g}, 1.50$ mmol). After 5 min stirring, the solution was cooled to $0{ }^{\circ} \mathrm{C}$, and a solution of EDC $(0.316 \mathrm{~g}, 1.65 \mathrm{mmol})$ in dry DCM $(5 \mathrm{ml})$ was added slowly. After $5 \mathrm{~min}$ at this temperature, the solution was allowed to warm to ambient temperature and stirring was continued for $16 \mathrm{hr}$. The solvent was removed in vacuo and the resulting solid was dissolved in EtOAc (30 ml). It was washed successively with $\mathrm{H}_{2} \mathrm{O}(3 \times 10 \mathrm{ml}), 5$ $\% \mathrm{HCl}$ solution $(3 \times 10 \mathrm{ml})$, saturated aqueous sodium carbonate solution $(3 \times 10 \mathrm{ml})$, brine $(3 \times 10 \mathrm{ml})$ and then dried over $\mathrm{MgSO}_{4}$. It was concentrated in vacuo yielding a colorless oil ( $0.46 \mathrm{~g})$, which was purified by column chromatography on silica gel in $20 \%$ ethyl acetate: petroleum ether giving a white solid $(0.44 \mathrm{~g}, 90 \%) . \mathrm{R}_{\mathrm{f}}: 0.3(40 \%$ ethyl acetate: petroleum ether). M.p.: $81-84{ }^{\circ} \mathrm{C} .[\alpha]_{\mathrm{D}}:+38.5(c=1$ in $\mathrm{MeOH})$. IR, $(\mathrm{KBr}) / \mathrm{cm}^{-1}: \quad 3304,2976,1688,1676 .{ }^{1} \mathrm{H}$ NMR $\delta: 7.51$ (s (br), 1H), 7.31-7.22 (m, $5 \mathrm{H}), 5.10$ (s (br), 1H), 4.32 (s (br), 1H), 3.34 (s (br), 2H), 2.41 (s (br), 1H), 2.13 (s (br), 1H), 1.85 (s (br), 4H), 1.45 (s, 9H). ${ }^{13} \mathrm{C}$ NMR $\delta$ : 171.3, 155.1, 143.0, 128.6, 125.9, 47.1, 28.4. Some signals missing due to line broadening. HRMS (ESI) calculated for $\mathrm{C}_{18} \mathrm{H}_{27} \mathrm{~N}_{2} \mathrm{O}_{3}[\mathrm{M}+\mathrm{H}]^{+}:$319.2022. Found: 319.2015 .

$2 S$-(1'S-Phenyl-ethylcarbamoyl)-pyrrolidine-1-carboxylic acid tert-butyl ester (24b) 
Prepared from $21(0.32 \mathrm{~g}, 1.50 \mathrm{mmol})$ in a similar manner to $24 \mathrm{a}$ using $(R)-1$ phenylethylamine. The crude product was purified by column chromatography on silica gel in $20 \%$ ethyl acetate: petroleum ether giving a white solid $(0.44 \mathrm{~g}, 90 \%)$. $\mathrm{R}_{\mathrm{f}}: 0.2$ (40 \% ethyl acetate: petroleum ether). M.p.: $98-101{ }^{\circ} \mathrm{C} .[\alpha]_{\mathrm{D}}:-130(c=1$ in $\mathrm{MeOH}) . \mathrm{IR},(\mathrm{KBr}) / \mathrm{cm}^{-1}$ : $3305,2977,1688,1675 .{ }^{1} \mathrm{H}$ NMR $\delta: 7.51$ (s (br), 1H), 7.31-7.25 (m, 5H), 5.10 (s (br), 1H), $4.33 \& 4.25$ (2 x m, 1H), 3.35 (s (br), 2H), 2.41 (s (br), 1H), 2.12 (s (br), 1H), 1.85 (s (br), 5H), 1.46 (s, 9H). ${ }^{13} \mathrm{C}$ NMR $\delta$ : 171.6, 154.1, 143.2, 130.7, 128.6, 127.1, 80.5, 48.6, 28.1. HRMS (ESI) calculated for $\mathrm{C}_{18} \mathrm{H}_{27} \mathrm{~N}_{2} \mathrm{O}_{3}[\mathrm{M}+\mathrm{H}]^{+}$: 319.2022. Found: 319.2007.

\section{S-Pyrrolidine-2-carboxylic acid (1' $R$-phenyl-ethyl)-amide (18a)}

To a solution of $24 \mathrm{a}(1.0 \mathrm{~g}, 3.14 \mathrm{mmol})$ in DCM $(2 \mathrm{ml})$ was added TFA $(2 \mathrm{ml}, 17$ mmol), and the solution was stirred at ambient temperature for $16 \mathrm{hr}$. It was then concentrated in vacuo, dissolved in $\mathrm{H}_{2} \mathrm{O}(40 \mathrm{ml})$, and the $\mathrm{pH}$ adjusted to $\sim 8$ by adding $\mathrm{Et}_{3} \mathrm{~N}$ dropwise, at $0{ }^{\circ} \mathrm{C}$. The product was then extracted with DCM $(3 \times 20 \mathrm{ml})$, dried over $\mathrm{MgSO}_{4}$, and concentrated in vacuo yielding an oil, which was purified on silica gel in 5\% MeOH:DCM, giving the product as a yellow oil $(0.62 \mathrm{~g}, 91 \%)$. $\mathrm{R}_{\mathrm{f}}: 0.5(10$ \% MeOH: DCM). $[\alpha]_{\mathrm{D}}:+21.5\left(c=1\right.$ in MeOH). IR, (Thin film) $/ \mathrm{cm}^{-1}: 3412,3263$, 2976, 1672. ${ }^{1} \mathrm{H}$ NMR $\delta$ : 7.97 (s (br), 1H), 7.35-7.21 (m, 5H), 5.09-5.04 (m, 1H), 3.91-3.86 (m, 1H), 3.08-2.92 (m, 2H), 2.22-2.10 (m, 1H), 1.93-1.87 (m, 1H), 1.77$1.70(\mathrm{~m}, 2 \mathrm{H}), 1.47(\mathrm{~d}, 3 \mathrm{H}, J=7.1 \mathrm{~Hz}) .{ }^{13} \mathrm{C}$ NMR $\delta: 173.6,144.8,128.6,127.3$, 126.0, 60.3, 49.2, 48.6, 30.6, 25.9, 21.5. HRMS (ESI) calculated for $\mathrm{C}_{13} \mathrm{H}_{19} \mathrm{~N}_{2} \mathrm{O}$ $[\mathrm{M}+\mathrm{H}]^{+}:$219.1497. Found: 219.1498.

\section{S-Pyrrolidine-2-carboxylic acid (1'S-phenyl-ethyl)-amide (18b)}

Prepared from $24 \mathrm{~b}(1.0 \mathrm{~g}, 3.14 \mathrm{mmol})$ in a similar manner to $\mathbf{1 8 a}$ to give $\mathbf{1 8 b}$ as a yellow oil (0.64 g, $94 \%)$. $\mathrm{R}_{\mathrm{f}}: 0.4(10 \% \mathrm{MeOH}: \mathrm{DCM})$. $[\alpha]_{\mathrm{D}}$ : - $48(c=1$ in $\mathrm{MeOH})$. IR, (Thin film) $/ \mathrm{cm}^{-1}$ : 3414, 3260, 2977, 1670. ${ }^{1} \mathrm{H}$ NMR $\delta: 8.08$ (s (br), 1H), 7.34$7.20(\mathrm{~m}, 5 \mathrm{H}), 5.30-5.01(\mathrm{~m}, 1 \mathrm{H}), 4.43-4.41(\mathrm{~m}, 1 \mathrm{H}), 3.49-3.10(\mathrm{~m}, 2 \mathrm{H}), 2.38-2.34(\mathrm{~m}$, $1 \mathrm{H}), 1.94-1.86(\mathrm{~m}, 3 \mathrm{H}), 1.48(\mathrm{~d}, 3 \mathrm{H}, J=7.2 \mathrm{~Hz}) .{ }^{13} \mathrm{C}$ NMR $\delta: 168.8,143.1,128.7$, 127.4, 125.8, 59.5, 50.3, 46.4, 30.2, 24.8, 22.0. HRMS (ESI) calculated for $\mathrm{C}_{13} \mathrm{H}_{19} \mathrm{~N}_{2} \mathrm{O}[\mathrm{M}+\mathrm{H}]^{+}:$219.1497. Found: 219.1497. 
$2 S$-[Methyl-(1'R-phenyl-ethyl)-carbamoyl]-pyrrolidine-1-carboxylic acid tertbutyl ester (25a)

To a solution of $24 \mathrm{a}(0.5 \mathrm{~g}, 1.57 \mathrm{mmol})$ in dry THF $(5 \mathrm{ml})$ at $-20{ }^{\circ} \mathrm{C}$, was added a 1.0M solution of LiHMDS in THF (1.62 ml, $1.62 \mathrm{mmol})$ slowly, while keeping the temperature below $-15{ }^{\circ} \mathrm{C}$. The solution was stirred for $30 \mathrm{~min}$., under nitrogen, at this temperature. Methyl iodide $(0.30 \mathrm{ml}, 3.93 \mathrm{mmol})$ was added slowly at $-20{ }^{\circ} \mathrm{C}$. The solution was stirred while allowing it to warm to ambient temperature. After $18 \mathrm{hr}$ the solution was quenched with $1 \mathrm{~N} \mathrm{HCl}(20 \mathrm{ml})$, and the majority (80\%) of the solvent was removed in vacuo. The remaining suspension was diluted with diethyl ether (40 $\mathrm{ml})$ and the organic phase was separated, washed with $1 \mathrm{~N} \mathrm{HCl}$ solution $(3 \times 10 \mathrm{ml})$, saturated aqueous sodium chloride solution ( $3 \times 10 \mathrm{ml}$ ), then dried over $\mathrm{MgSO}_{4}$, and concentrated in vacuo. The crude product was purified by column chromatography on silica gel in $30 \%$ ethyl acetate: petroleum ether giving a yellow oil $(0.50 \mathrm{~g}, 92 \%)$. $\mathrm{R}_{\mathrm{f}}$ : 0.3 (20\% ethyl acetate: petroleum ether). $[\alpha]_{\mathrm{D}}:+48.3(c=0.6$ in $\mathrm{MeOH})$. IR, (Thin film) $/ \mathrm{cm}^{-1}: 2978,1697,1654 .{ }^{1} \mathrm{H}$ NMR (two rotamers present) $\delta: 7.34-7.20(\mathrm{~m}, 5 \mathrm{H})$, 6.15-6.05 (m, 1H), $5.02 \& 4.60(2 \times \mathrm{m}, 1 \mathrm{H}), 3.70-3.35(\mathrm{~m}, 2 \mathrm{H}), 2.82 \& 2.70(2 \times \mathrm{s}$, $3 \mathrm{H}), 2.12-2.08(\mathrm{~m}, 2 \mathrm{H}), 1.95-1.88(\mathrm{~m}, 2 \mathrm{H}), 1.65(\mathrm{~s}, 3 \mathrm{H}), 1.48 \& 1.35(2 \mathrm{x} \mathrm{s}, 9 \mathrm{H}) .{ }^{13} \mathrm{C}$ NMR (two rotamers present) $\delta$ : 173.6, 153.4, 140.3, 128.8, 128.2, 127.0, 56.7, 50.5, 46.8, 30.6, 29.5, 28.5, 24.4, 15.6. HRMS (ESI) calculated for $\mathrm{C}_{19} \mathrm{H}_{29} \mathrm{~N}_{2} \mathrm{O}_{3}[\mathrm{M}+\mathrm{H}]^{+}$: 333.2178. Found: 333.2171.

\section{S-[Methyl-(1'S-phenyl-ethyl)-carbamoyl]-pyrrolidine-1-carboxylic acid tert- butyl ester (25b)}

Prepared from 24b $(0.5 \mathrm{~g}, 1.57 \mathrm{mmol})$ in a similar manner to 25a. The crude product was purified by column chromatography on silica gel in $30 \%$ ethyl acetate: petroleum ether giving a yellow oil $(0.52 \mathrm{~g}, 98 \%)$. $\mathrm{R}_{\mathrm{f}}$ : 0.2 (20\% ethyl acetate: petroleum ether). $[\alpha]_{\mathrm{D}}:-102.3\left(c=0.85\right.$ in MeOH). IR, (Thin film) $/ \mathrm{cm}^{-1}: 2978,1696,1653 .{ }^{1} \mathrm{H} \mathrm{NMR}$ (two rotamers present) $\delta: 7.34-7.21(\mathrm{~m}, 5 \mathrm{H}), 6.04(\mathrm{~m}, 1 \mathrm{H}), 4.67 \& 4.55(2 \mathrm{x} \mathrm{m}, 1 \mathrm{H})$, 3.68-3.45 (m, 2H), $2.73 \& 2.68(2 \times \mathrm{s}, 3 \mathrm{H}), 2.08-2.02(\mathrm{~m}, 2 \mathrm{H}), 1.89-1.85(\mathrm{~m}, 2 \mathrm{H})$, $1.58(\mathrm{~s}, 3 \mathrm{H}), 1.48 \& 1.45(2 \mathrm{x} \mathrm{s}, 9 \mathrm{H}) .{ }^{13} \mathrm{C} \mathrm{NMR}$ (two rotamers present) $\delta: 172.9$, 151.3, 141.6, 128.5, 128.4, 127.2, 57.8, 50.6, 47.1, 29.2, 28.9, 28.5, 23.5, 15.2. HRMS (ESI) calculated for $\mathrm{C}_{19} \mathrm{H}_{29} \mathrm{~N}_{2} \mathrm{O}_{3}[\mathrm{M}+\mathrm{H}]^{+}:$333.2178. Found: 333.2166. 


\section{S-Pyrrolidine-2-carboxylic acid methyl-(1'R-phenyl-ethyl)-amide (18c)}

To a solution of $25 \mathrm{a}(0.3 \mathrm{~g}, 0.903 \mathrm{mmol})$ in DCM $(0.6 \mathrm{ml})$ was added TFA $(0.6 \mathrm{ml}$, $2.6 \mathrm{mmol}$ ), and the solution was stirred at ambient temperature for $16 \mathrm{hr}$. It was concentrated in vacuo, dissolved in $\mathrm{H}_{2} \mathrm{O}(40 \mathrm{ml})$, and the $\mathrm{pH}$ was adjusted to $\sim 8$ by adding $\mathrm{Et}_{3} \mathrm{~N}$ dropwise, at $0{ }^{\circ} \mathrm{C}$. The product was then extracted with $\mathrm{DCM}(3 \times 20$ $\mathrm{ml}$ ), dried over $\mathrm{MgSO}_{4}$, and concentrated in vacuo yielding an oil, which was purified on silica gel in 5\% MeOH:DCM, giving the product as a yellow oil (0.18 g, $86 \%)$. $\mathrm{R}_{\mathrm{f}}$ : $0.6(10 \% \mathrm{MeOH}: \mathrm{DCM}) \cdot[\alpha]_{\mathrm{D}}:+41(c=1$ in $\mathrm{MeOH}) . \mathrm{IR}$, (Thin film) $/ \mathrm{cm}^{-1}: 3438$, 2979, 1697, 1655. ${ }^{1} \mathrm{H}$ NMR (two rotamers present) $\delta: 8.10$ (d (br), 1H), 7.40-7.22 (m, $5 \mathrm{H}), 5.92(\mathrm{q}, 1 \mathrm{H}, J=7.1 \mathrm{~Hz}), 5.30 \& 4.74,3.98 \& 3.69(4 \mathrm{x} \mathrm{m}, 1 \mathrm{H}), 3.49-3.39 \&$ $3.18-2.90(2 \times \mathrm{m}, 2 \mathrm{H}), 2.76 \& 2.71(2 \mathrm{x} \mathrm{s}, 3 \mathrm{H}), 2.51-1.58(\mathrm{~m}, 4 \mathrm{H}), 1.50 \& 1.47(2 \mathrm{x} \mathrm{d}$, $3 \mathrm{H}, J=7.1 \mathrm{~Hz}$ ). ${ }^{13} \mathrm{C}$ NMR (two rotamers present) $\delta: 172.1 \& 169.3,142.8 \& 138.5$, $129.1,128.6,127.1,60.3 \& 58.1,52.3 \& 48.4,47.1 \& 46.6,30.6 \& 29.7,25.8 \& 25.6$, 22.2, 15.6. HRMS (ESI) calculated for $\mathrm{C}_{14} \mathrm{H}_{21} \mathrm{~N}_{2} \mathrm{O}[\mathrm{M}+\mathrm{H}]^{+}:$233.1654. Found: 233.1661 .

\section{S-Pyrrolidine-2-carboxylic acid methyl-(1'S-phenyl-ethyl)-amide (18d)}

Prepared from 25b $(0.3 \mathrm{~g}, 0.903 \mathrm{mmol})$ in a similar manner to $18 \mathrm{c}$ to give an oil, which was purified on silica gel in 5\% MeOH:DCM, giving the product as a yellow solid (0.19 g, $88 \%)$. Rf: $0.5(10 \% \mathrm{MeOH}: \mathrm{DCM})$. M.p.: $172-175^{\circ} \mathrm{C} .[\alpha]_{\mathrm{D}}:-120(c=$ 1 in $\mathrm{MeOH})$. IR, $(\mathrm{KBr}) / \mathrm{cm}^{-1}$ : 3436, 2980, 1698, 1650. ${ }^{1} \mathrm{H}$ NMR (two rotamers present) $\delta: 7.39-7.21(\mathrm{~m}, 5 \mathrm{H}), 5.93(\mathrm{q}, 1 \mathrm{H}, J=7.1 \mathrm{~Hz}),, 5.05 \& 4.84,(2 \mathrm{x} \mathrm{m}, 1 \mathrm{H})$, 3.56-3.51 \& 3.46-2.38 (2 x m, 2H), 2.69 (s, 3H), 2.54-2.47 (m, 1H), 2.21-2.14 (m, 1H), 2.08-2.00 (m, 1H), 1.88-1.82 (m, 1H), $1.55(\mathrm{~d}, 3 \mathrm{H}, J=7.2 \mathrm{~Hz}) .{ }^{13} \mathrm{C}$ NMR (two rotamers present) $\delta$ : 169.3, 138.8, 129.3, 128.8, 127.2, 58.0, 52.4, 46.7, 29.7, 29.1, 25.3, 15.2. HRMS (ESI) calculated for $\mathrm{C}_{14} \mathrm{H}_{21} \mathrm{~N}_{2} \mathrm{O}[\mathrm{M}+\mathrm{H}]^{+}:$233.1654. Found: 233.1655 .

General procedure for the Michael Addition reaction of aldehydes and $\beta$ nitrostyrene.

To a solution of the $\beta$-nitrostyrene $(0.15 \mathrm{~g}, 1 \mathrm{mmol})$ in dry DCM $(1 \mathrm{ml})$ was added the relevant catalyst $(0.05 \mathrm{mmol})$, followed by the aldehyde $(1.5 \mathrm{mmol})$. The reaction was stirred at ambient temperature for 48 or 72 hours, under a nitrogen atmosphere. It was 
then diluted with chloroform $(5 \mathrm{ml})$ and treated with $1 \mathrm{~N} \mathrm{HCl}(4 \mathrm{ml})$, while stirring vigorously. The aqueous layer was extracted with chloroform and the combined organic layers were dried over $\mathrm{MgSO}_{4}$ and concentrated in vacuo. The crude product was purified by column chromatography on silica gel with 5\% EtOAc: petroleum ether. For example, 2-propyl-4-nitro-3-phenylbutyraldehyde (16): $\mathrm{R}_{\mathrm{f}}$ : 0.6 (20\% ethyl acetate: petroleum ether). Analytical data was as reported in the literature. ${ }^{12}$ HPLC data: Chiralcel OD-H column; flow $1.6 \mathrm{ml} / \mathrm{min}$ using 90/10 hexane/2-propanol, syn $\mathrm{t}_{\mathrm{r}}$ $=6.4 \mathrm{~min}(S, R)$ and $8.9 \mathrm{~min}(R, S)$, anti $\mathrm{t}_{\mathrm{r}}=7.6 \mathrm{~min}$ and $13.0 \mathrm{~min}$.

\section{X-Ray data}

The data were collected at $150(2) \mathrm{K}$ on a Bruker Apex II CCD diffractometer. The structures were solved by direct methods ${ }^{13,14}$ and refined on $\mathrm{F}^{2}$ using all the reflections. ${ }^{14}$ All the non-hydrogen atoms were refined using anisotropic atomic displacement parameters and hydrogen atoms bonded to carbon were inserted at calculated positions using a riding model. The $\mathrm{H}$ atoms bonded to nitrogen or oxygen were located from difference maps and refined with thermal parameters riding on the carrier atoms.

Crystal data for $11 b . \mathrm{C}_{20} \mathrm{H}_{28} \mathrm{~N}_{2} \mathrm{O}_{3}, M=344.44$. orthorhombic, $a=6.5297(9), b=$ 16.557(2), $c=17.425(3) \AA, U=1883.9(5) \AA^{3}, T=150(2) \mathrm{K}$, space group $\mathrm{P} 22_{1} 22_{1}, Z=$ 4, 14987 reflections measured, 1930 independent reflections $\left(R_{\mathrm{int}}=0.0534\right)$. The final $w \mathrm{R}(F 2)$ was 0.0949 (all data) and $\mathrm{R} 1$ was 0.0374 for $I>2 \mathrm{~s}(I)$. CCDC No. 687387.

Crystal data for 17b.TsOH. $\mathrm{C}_{22} \mathrm{H}_{30} \mathrm{~N}_{2} \mathrm{O}_{4} \mathrm{~S}, M=418.54$. orthorhombic, $a=7.8627(11)$, $b=12.6431(18), c=21.679(3) \AA, U=2155.1(5) \AA^{3}, T=150(2) \mathrm{K}$, space group $\mathrm{P} 2{ }_{1} 2_{1} 2_{1}, Z=4,19139$ reflections measured, 4406 independent reflections $\left(R_{\text {int }}=\right.$ 0.0571 ) which were used in all calculations. ${ }^{13}$ The final $w \mathrm{R}(F 2)$ was 0.0812 (all data) and R1 was 0.0397 for $I>2 \mathrm{~s}(I)$. CCDC No. 749092.

Crystal data for 22g. $\mathrm{C}_{19} \mathrm{H}_{28} \mathrm{~N}_{2} \mathrm{O}_{3}, M=332.43$. orthorhombic, $a=9.9790(9), b=$ 16.6480(15), $c=23.276(2) \AA, U=3866.9(6) \AA^{3}, T=150(2) \mathrm{K}$, space group P $2{ }_{1} 2_{1} 2_{1}$, $Z=8$, (two independent molecules in the asymmetric unit), 34133 reflections measured, 4427 independent reflections $\left(R_{\text {int }}=0.0801\right)$. The final $w \mathrm{R}(F 2)$ was 0.0820 (all data) and R1 was 0.0400 for $I>2$ s(I). CCDC No. 749093. 


\section{Acknowledgements}

We are grateful to Strands I \& III of the Irish Government's National Development Plan (2000-2006) Technological Sector Research Program, for funding for SK (Grant CRS/01/TA02) and JW (Grant PP06/TA02) and ITT Dublin PhD continuation funding PP06/TA02C. We are thankful to Frances Heaney and John Stephens for helpful discussions.

\section{References and Notes}

1. A non-exhaustive list of recent references includes (a) Cheng, Y-Q.; Bian, Z.; He, Y-B.; Han, F-S.; Kang, C-Q.; Ning, Z-L.; Gao, L-X. Tetrahedron: Asymmetry 2009, 20, 1753-1758. (b) Okuyama, Y.; Nakano, H.; Watanabe, Y.; Makabe, M.; Takeshita, M.; Uwai, K.; Kabuto, C.; Kwon, E. Tetrahedron Lett. 2009, 50, 193-197. (c) Zhao, J-Q.; Gan, L-H. Eur. J. Org. Chem. 2009, 2661-2665. (d) Ni, B.; Zhang, Q.; Dhungana, K.; Headley, A. Org. Lett. 2009, 11, 1037-1040. (e) Tan, B., Zeng, X.; Lu, Y.; Chua, P.; Zhong, P. Org. Lett. 2009, 11, 1927-1930. (f) Pansare, S.; Kirby, R. Tetrahedron 2009, 65, 4557-4561. (g) Wang, C.; Yu, C.; Liu, C.; Peng, Y. Tetrahedron Lett. 2009, 50, 2363-2366. (h) "Enantioselective Organocatalysis: Reactions and Experimental Procedures" P. Dalko, 2007, Wiley-VCH. (i) "Asymmetric Organocatalysis: From Biomimetic Concepts to Applications in Asymmetric Synthesis" A. Berkessel and H Gröger, 2005, Wiley-VCH. (j) Palomo, C.; Vera, S.; Mielgo, A.; GómezBengoa, E. Angew. Chem. Int. Ed. 2006, 45, 5984-5987 and references cited therein.

2. For a selection of recent reviews see (a) Lattanzi, A., Chem. Commun. 2009, 1452-1463. (b) Dondoni, A., Massi, A. Angew. Chem. Int. Ed. 2008, 47, 4638-4660. (c) Melchiore, P., Marigo, M., Carlone, A., Bartoli, G. Angew. Chem. Int. Ed. 2008, 47, 6138-6171. (d) Kotsuki, H., Ikishima, H., Okuyama, A. Heterocycles 2008, 75, 757-797. (e) Longbottom, D., Franckevičius, V., Kumarn, S., Oelke, A., Wascholowski, V., Ley, S. Aldrichim. Acta 2008, 41, 3-11. (f) Sulzer-Mossé, S.; Alexakis, A. Chem. Commun. 2007, 3123-3135. (g) Vicario, J.L.; Badia, D.; Carillo, L. Synthesis 2007, 2065-2092. (h) Tsogoeva, S. Eur. J. Org. Chem. 2007, 
1701-1716. (i) Mukherjee, S., Yang, J.W., Hoffman, S., List, B. Chem. Rev. 2007, 107, 5471-5569. (j) Gaunt, M., Johansson, C., McNally, A., Vo, N. Drug Discovey Today 2007, 12, 8. (k) Pellissier, H., Tetrahedron 2007, 63, 9267-9331. (1) Mossé, S., Andrey, O., Alexakis, A. Chimia 2006, 60, 216-219. (m) Cobb, A., Shaw, D., Longbottom, D., Gold, J., Ley, S. Org. Biomol. Chem. 2005, 3, 84-96. (n) Notz, W.; Tanaka, F.; Barbas, C. III. Acc. Chem. Res. 2004, 37, 580-591. (o) Berner, O. M., Tedeschi, L., Enders, D. Eur. J. Org. Chem. 2002, 1877-1894. and references cited therein.

3. Zhu, S.; Yu, S.; Ma, D. Angew. Chem. Int. Ed. 2008, 47, 545-548.

4. Lombardo, M.; Chiarucci, M.; Quintavalla, A.; Trombini. C. Adv. Synth. Catal. 2009, 351, 2801-2806.

5. (a) Wiesner, M.; Upert, G.; Angelici, G.; Wennemers, H. J. Am. Chem. Soc. 2010, 132, 6-7. (b) Wiesner, M.; Revell, J.; Tonazzi, S.; Wennemers, H. J. Am. Chem. Soc. 2008, 130, 5610-5611. (c) Wiesner, M.; Revell, J.; Wennemers, H. Angew. Chem. Int. Ed. 2008, 47, 1871-1874. and references cited therein.

6. Planas, L.; Pérard-Viret, J.; Royer, J. Tetrahedron: Asymmetry 2004, 15, 2399-2403.

7. (a) Kelleher, F., Kelly, S. Tetrahedron Lett. 2006, 47, 3005-3008. (b) Kelleher, F., Kelly, S. Tetrahedron Lett. 2006, 47, 5247-5250. (c) Kelleher, F., Kelly, S., McKee, V. Tetrahedron 2007, 62, 9235-9242.

8. Seebach, D., Golinski, J. Helv. Chim. Acta, 1981, 64, 1413-1423.

9. Chimni, S.; Singh, S.; Mahajan, D. Tetrahedron: Asymmetry 2008, 19, 2276-2284.

10. Tang, Z.; Jiang, F.; Cui, X.; Gong, L., Mi, A.; Jiang, Y.; Wu, Y. Proc. Natl. Acad. Sci. USA 2004, 101, 5755-5760.

11. Confalone, P., Huie, E., Ko, S., Cole, G. J. Org. Chem. 1988, 53, 482-487.

12. (a) Alexakis, A.; Andrey, O. Org. Lett. 2002, 4, 3611-3614. (b) Betancort, J.; Barbas III, C.. Org. Lett. 2001, 3, 3737-3740.

13. SIR-2004, Burla, M., Caliandro, R. , Camalli, M., Carrozzini, B., Cascarano, G., Caro, L., Giacovazzo, C., Polidori, G., and Spagna, R., J. Appl. Cryst., 2005, 38, 381.

14. Sheldrick, G.M. Acta Cryst. 2008, A64, 112-122. 